\title{
EFEITO DO COMPLEXO BROCA/PODRIDÕES NA FERMENTAÇÃO ETANÓLICA
}

\author{
EVELINE BLUMER \\ Química Tecnológica
}

Orientador: Prof. Dr. JOSÉ PAULO STUPIELLO

Dissertação apresentada à Escola Superior de Agricultura "Luiz de Queiroz" da Universidade de São Paulo, para obtenção do título de Mestre em Ciências. Área de Concentração: Ciência e Tecnologia de Alimentos.

P I R A C I C A B A

Estado de São Paulo - Brasil

Junho - $19 \overline{9}$ 
Ficha catalográfica preparada pela seção de Livros da Divisão de Biblioteca e Documentação - PCLQ/USP

\footnotetext{
Blumer, Eveline

B658e Efeito do complexo broca/podridōes na fermentação etanólica. Piracicaba, 1992. $66 \mathrm{p}$.

Diss. (Mestre) - EsALQ Bibliografia.

1. Cana-de-açúcar - Doença - Efeito 2. Cana-de-açúcar Praga - Efeito 3. Cana-de-açúcar - Tecnologia 4. Matéria prima - Qualidade I. Escola superior de Agricultura Luiz de Queiroz, Piracicaba 


\title{
EFEITO DO COMPLEXO BROCA/PODRIDÕES NA FERMENTAÇÃO ETANÓLICA
}

\author{
EVELINE BLUMER \\ Química Tecnológica
}

Aprovada em 22.12.1994

Comissão Julgadora:

Prof. Dr José Paulo Stupiello

ESALQ/USP

Prof. Dr. Antonio Joaquim de Oliveira

ESALQ/USP

Prof. Dra. Márcia J.R. Mutton

UNESP/USP

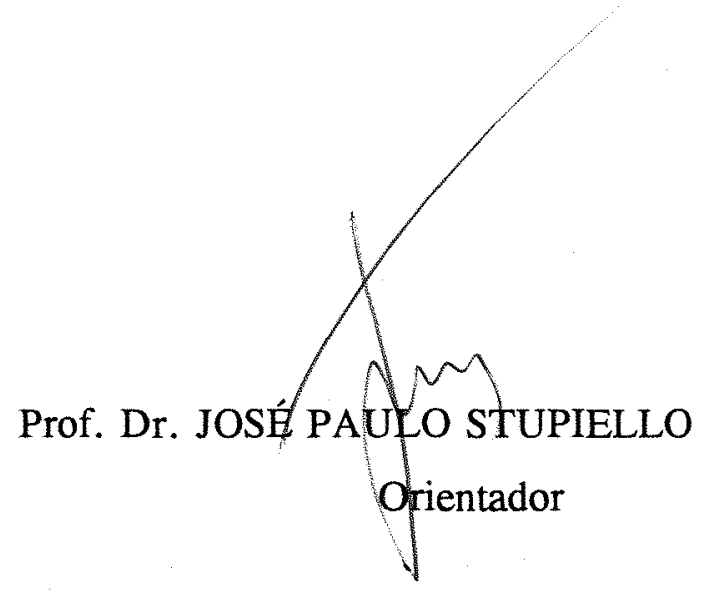


À meus pais,

Leonardo e Antonieta,

\section{DEDICO}




\section{AGRADECIMENTOS}

A autora expressa seus agradecimentos,

Ao Prof. Dr. JOSÉ PAULO STUPIELLO pela orientação.

Ao Prof. Dr. FERNANDO VALADARES NOVAES pelos incentivos e sugestões.

À amiga ZELINDA AGUIAR JORDĀO, Química Tecnológica, pelo auxílio na realização prática e incentivo durante o trabalho.

Aos funcionários do Departamento de Ciência e Tecnologia Agroindustrial do Setor de Açúcar e Álcool.

Ao Eng ${ }^{\circ} \mathrm{Agr}^{\circ}$ DENIS SCHIAVINATO um agradecimento especial, pois acompanhou passo a passo, todas as etapas deste trabalho.

À MARTA e SILVIA que, além do incentivo, souberam compreender minha luta em todos os momentos do curso.

Á CLOTILDE MARIA BATOCHIO CUNHA, minha incentivadora e secretária, pelo trabalho de digitação.

Enfim, a todos que de alguma maneira me acompanharam nesta trajetória que chega ao seu final. 


\section{ÍNDICE}

Página

RESUMO........................................................... v

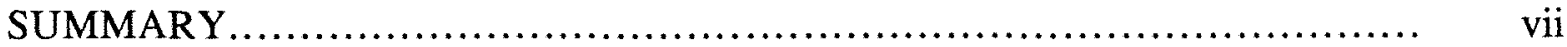

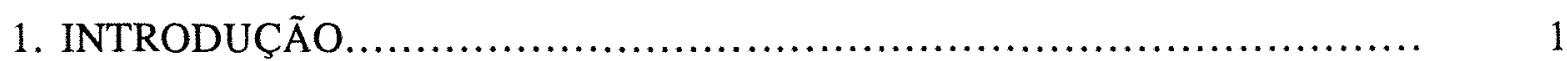

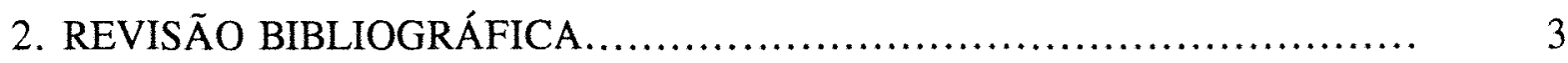

2.1. Ciclo da Broca da Cana-de-Açúcar.................................. 3

2.1.1. Ciclo da Praga............................................. 5

2.2. Ação dos Patógenos e Defesa das Plantas............................. 6

2.2.1. Podridão Vermelha.......................................... 7

2.2.2. Ciclo da Doença............................................. 8

2.3. Prejuízos Causados pelo Complexo Broca/Podridões.................... 9

2.3.1. Prejuízos de Ordem Agrícola................................... 9

2.3.2. Prejuízos de Ordem Tecnológica............................. 12

2.3.3. Efeitos sobre a Fermentação Etanólica......................... 17

2.4. Critérios de Avaliação da Infestação da Broca de Cana-de-Açúcar....... 19

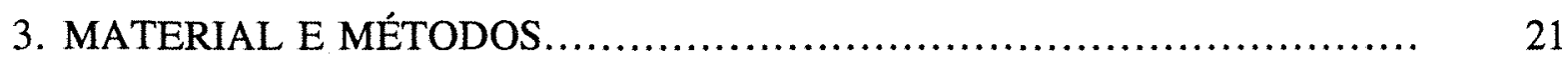

3.1. Material...................................................... 21

3.2. Métodos........................................................ 21

3.3. Cálculo do Índice Volumétrico de Doença (I.V.D.)...................... 22

3.4. Cálculo da Eficiência de Fermentação............................... 22

3.5. Cálculo da Produtividade de Fermentação............................. 23

3.6. Condições Operacionais........................................ 24

3.7. Procedimento Experimental....................................... 24 
3.7.1. Preparo do Inóculo.............................................. 25

3.7.2. Preparo do Mosto............................................ 26

3.7.3. Recuperação do Fermento.................................... 26

3.8. Descrição de um Ensaio Típico.................................... 26

4. RESULTADOS E DISCUSSÃO......................................... 29

4.1. Cálculo do I.V.D. nas Canas Atacadas pelo Complexo Broca-

Podridões.......................................................... 29

4.2. Análises do Caldo Extraído........................................ $\quad 30$

4.2.1. Brix e Açúcar Total.......................................... 30

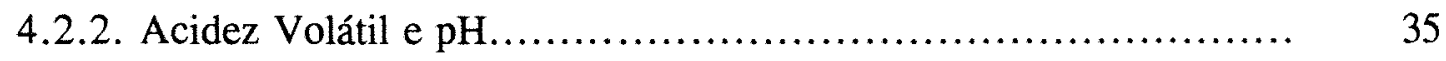

4.3. Tempo de Fermentação.............................................. 35

4.4. Eficiência de Fermentação.............................................. 38

4.5. Produtividade de Fermentação........................................ 48

4.6. $\mathrm{pH}$ durante as Fermentações............................................. 49

4.7. Acidez Volátil durante as Fermentações................................ 53

4.8. Metabolismo Celular................................................... 53

5. CONCLUSÕES.................................................. 59

REFERÊNCIAS BIBLIOGRÁFICAS.................................. 60 


\section{EFEITO DO COMPLEXO BROCA/PODRDÕES NA FERMENTAÇÃO ETANÓLICA}

Autora: EVELINE BLUMER

Orientador: Prof. Dr. JOSÉ PAULO STUPIELLO

\section{RESUMO}

Estudou-se o efeito do complexo broca-podridões na fermentação etanólica, onde a intensidade do complexo foi medida através do índice volumétrico de doença, que leva em consideração o volume da cana-de-açúcar e o volume da doença (broca + podridões). Durante o experimento foi observado que índices em torno de $8 \%$ de infestação no mosto, quando comparado com o mosto sadio (sem a presença da broca e da podridão), apresentou valores de brix e açúcar total inferiores, indicando a deterioração da cana-de-açúcar induzida pela broca e pelos microrganismos invasores que se aproveitaram do orifício aberto pela broca para se alojarem no interior do colmo, degradando os açúcares e produzindo metabólitos como ácidos orgânicos. $\mathrm{O}$ valor de $\mathrm{pH}$ também foi afetado havendo sempre uma tendência de ser menor para o colmo contaminado pelo complexo, indicando uma maior acidez.

Durante as fermentações pode-se observar que a produtividade e a eficiência eram afetadas negativamente, principalmente com a infestação em torno de $8 \%$, concluindo-se que para estes índices de infestação a presença de metabólitos inibidores no mosto era mais acentuada. 
A eficiência fermentativa foi afetada positivamente quando eram baixos os índices volumétricos da doença.

Quando se comparou índices volumétricos de doença de mesma ordem, observou-se que eles afetaram diferentemente a eficiência fermentativa. 


\section{EFFECTS OF BORER-RED ROT COMPLEX IN ETHANOLIC FERMENTATION}

Author: EVELINE BLUMER

Adviser: Prof. Dr. JOSÉ PAULO STUPIELLO

\section{SUMMARY}

The effect of borer-red rot complex on the ethanolic fermentation was studied, where intensity of said complex was evaluated by the disease volumetric index, which takes into considerations sugar cane volume and disease volume (borer + rot). During the study it was observed that values around $8 \%$ in the infected wort, when compared to the wort free of the complex borer-rot, presented lowewr brix and total sugar values, indicator of sugar cane deterioration (producing of organic acids) by borer and invasive microrganisms through the orifice done bu the borer. The $\mathrm{pH}$ was also affected as shown by the lower values presented by the infected stalks.

The produtivity and efficiency fermentation was negatively affected, mainly with $8 \%$ infestation complex, possibly due to the presence of metabolic inhibitors.

The fermentation efficiency was positively affected when the disease volumetric index was low.

When same disease volumetric indexes were compared they are observed to affected the fermentation efficiency differently. 


\section{INTRODUÇÃO}

A agroindústria da cana-de-açúcar é uma das mais importantes do país, devido aos derivados que são obtidos durante o processamento da cana-de-açúcar e que são utilizados em outros setores industriais ou exportados.

Nos dias atuais muito se fala em qualidade e produtividade, e essa consciência está cada vez mais enquadrada no cotidiano do setor.

Para se falar em qualidade de produto acabado é necessário que se tenha qualidade de matéria-prima, e nessa área existem fatores como preparo de solos, adubação, escolha de variedades adequadas, plantios, pragas e doenças da cana-de-açúcar que interferem negativamente causando prejuízos irreparáveis que afetarão diretamente a produtividade industrial. Dentre os fatores citados a broca da cana-de-açúcar juntamente com a podridão vermelha é o complexo mais conhecido nas industrias do setor pelos prejuízos que causam e pela ampla distribuição nos canaviais paulistas e tambám da América. A espécie mais comum da broca de cana de açúcar é a Diatraea saccharalis que afeta diretamente a produtividade agrícola ao se alimentar dos tecidos da cana-de-açúcar ocasionando aquebra ou a morte da planta.

As perdas causadas pela broca são cauculadas normalmente através de índices de infestação; entretanto estes índices são imperfeitos porque muitas vezes não consideram as perdas totais causadas especialmente pelos altos níveis de infestação no campo e pelas podridões que acompanham a broca.

Além dessas perdas diretas que ocorrem no campo, tem-se ainda as perdas indiretas na industrialização do açúcar e nas fermentações etanólicas, ocasionadas 
principalmente pelas podridões que acompanham a broca da cana; caracterizada principalmente pela inversão da sacarose e produção de metabólitos inibidores através dos orifícios abertos pela broca, penetram, além do fungo que causa a podridão vermelha, Colleotrichum falcatum, microrganismos que podem trazer problemas à fermentação, pois concorrem com as leveduras na assimilação dos açúcares produzindo metabólitos e diminuindo a produção de álcool pelas leveduras, ocasionando um menor rendimento fermentativo.

Esses problemas relacionados com a presença da broca nos canaviais e com os conseqüentes prejuízos agrícolas e industriais representados por ela, tem sido extensivamente estudado em vários países: Havaí, Estados Unidos, Cuba e também no Brasil; porém, quase a totalidade desses trabalhos se preocuparam em avaliar as perdas ocasionadas no campo, em quantidade de sacarose perdida por tonelada de cana por área, concluindo-se que esses danos chegaram a causar prejuízos de alguns milhões de dólares por safra.

Este trabalho tem por objetivo, avaliar o efeito do complexo broca-podridões da cana-de-açúcar durante a fermentação etanólica, tomando como base o volume do colmo e o volume da doença, denominado de "Índice Volumétrico de Doença" (IVD). 


\section{REVISÃo BIBLIOGRÁFICA}

\subsection{Ciclo da Broca da Cana-de-Açúcar}

A primeira notícia sobre a presença da broca da cana-de-açúcar no Brasil foi publicada na revista "O Auxiliador da Indústria Nacional", em 1859. Esta revista noticiou que em 1839 ou 1840, foi constatado, no Município de Campos (RJ) e em Santa Catarina, uma lagarta que assolou os canaviais e mais tarde apareceu também na Bahia (GUAGLIUMI, 1972).

Segundo BERGAMIN (1948), a broca da cana-de-açúcar é classificada como um microlepdóptero da família Crambidae, gênero Diatraea, espécie saccharalis.

Como ALMEIDA \& SOUZA (1936), a cana-de-açúcar só é atacada pela broca quando essa se encontra em seu estado larvário, onde, a mais conhecida é a Diatraea saccharalis Fabricius, existindo porém, muitas outras espécies no Brasil e em diversos países, relacionados na Tabela 1. 
TABELA 1 - Espécies de Diatraea existentes no Brasil e em outros países

\begin{tabular}{|c|c|c|}
\hline Diatraea & Classificador & País \\
\hline Amnemonella & Dyar & Brasil - Paraná \\
\hline Angustella & Dyar & Brasil - Paraná \\
\hline Bellifactella & Dyar & Brasil - Paraná \\
\hline Berthellus & Schaus & Brasil - Paraná \\
\hline Canella & Hampson & $\begin{array}{l}\text { Brasil, Trinidad, Guiana, } \\
\text { Grenada }\end{array}$ \\
\hline Continents & Dyar & Brasil - Paraná \\
\hline Culmicolela & Zeller & Colombia \\
\hline Grandiosella & Dyar & México \\
\hline Instructella & Dyar & México \\
\hline Lineolata & Walker & $\begin{array}{l}\text { Cuba, Venezuela, México, } \\
\text { Brasil }\end{array}$ \\
\hline Magnifactella & Dyar & México \\
\hline Pallidostricta & Dyar & Brasil - São Paulo \\
\hline Mauriciella & Walker & Mauritius \\
\hline Minimifacta & Dyar & Trinidad \\
\hline Pedibarbata & Dyar & Guiana Francesa \\
\hline Pedidcota & Dyar & México \\
\hline Saccharallis & Fabricius & Guiana Inglesa, Brasil \\
\hline Strizipenella & Dyar & Brasil \\
\hline Venosalis & Dyar & Estados Unidos da América \\
\hline Zeacolella & Dyar & Estados Unidos da América \\
\hline
\end{tabular}

Fonte: ALMEIDA \& SOUZA (1936) 


\subsubsection{Ciclo da Praga}

a) Ovo

A fêmea da Diatraea saccharalis F., depois de fecundada faz a postura dos ovos, os quais são considerados como sendo o primeiro estágio do ciclo vital desse inseto (ALMEIDA \& SOUZA, 1936). No artigo "Pragas da Cultura da Cana-de-Açúcar" COPERSUCAR (1983), a quantidade de ovos colocados por uma fêmea adulta é muito variável, sendo esta variação bastante importante para posterior sucesso das populações infestantes da broca.

O ovo tem a forma elíptico-ovolada, bem achatado, medindo cerca de $1,13 \mathrm{~mm}$ de comprimento por $0,85 \mathrm{~mm}$ de diâmetro. O número de ovos na postura varia de 3 a 5 até 50. Para o completo desenvolvimento do embrião há necessidade de um tempo médio, variável com a temperatura e outras condições climáticas, de 4 a 9 dias. Em casos de muita chuva e excesso de frio, o tempo para esse desenvolvimento pode se prolongar por até 30 dias, havendo casos em que o desenvolvimento do embrião fica totalmente prejudicado. Durante esse tempo, o ovo vai tomando uma coloração mais escura, pardacenta, principalmente quando está perto a eclosão. Geralmente esta ocorre de manhã em dias mais quentes e à tarde em dias mais frios (ALMEIDA \& SOUZA, 1936; BERGAMIN, 1948; VALSECHI et al., 1976).

\section{b) Larva (Broca)}

É nessa fase de crescimento que a broca se alimenta diretamente da cana, causando sérios prejuízos. Esta ainda passa por subestágios conhecidos tecnicamente como "instars" larvais.

A larva desenvolvida mede cerca de $25 \mathrm{~mm}$ de comprimento por 3 a 3,5 de diâmetro. As lagartas que nascem de outubro a abril no Estado de São Paulo evoluem muito mais rapidamente e as variações verificadas são devidas às ocilações de temperatura (BERGAMIN, 1948). 
Alimenta-se a princípio, logo que nasce, do parênquima das folhas; em seqüência, ela desce para o colmo onde inicia a sua ação prejudicial (ALMEIDA \& SOUZA, 1936; BERGAMIN, 1948; VALSECHI et al., 1976).

\section{c) Pupa}

ALMEIDA \& SOUZA (1936) e VALSECHI et al. (1976), descrevem que no estágio de pupa ocorrem os chamados fenômenos de ninfose.

Para BERGAMIN (1948), o estado pupal pode variar de 6 a 14 dias; terminando esse estado, o inseto passa a adulto.

\section{d) Adulto}

Segundo GALLO (1953, 1954 e 1963), diversos fatores influem no desenvolvimento da broca durante seu ciclo vital. Dentre estes, podem ser agrupados como principais: fatores físicos e biológicos. Os fatores físicos seriam as condições climáticas,

principalmente a temperatura; em altitudes até $150 \mathrm{~m}$ o ciclo evolutivo é curto, podendo haver até 8 gerações anuais. Em altitudes maiores (mais frias) o período larval é mais longo, ocorrendo o que se costuma chamar de "geração hibernante", onde geralmente ocorrem 4 a 5 gerações anuais. A influência da umidade no desenvolvimento da broca é controvertida. Já os fatores biológicos têm grande importância na vida da broca; são os inimigos naturais, que podem infestar os ovos ou a própria lagarta, contribuindo para reduzir ou controlar as populações da broca.

\subsection{Ação dos Patógenos e Defesas das Plantas}

$\mathrm{O}$ ataque dos patógenos às plantas pode ser dividido em mecanismos de ação mecânica e de ação química, que são mais numerosos, produzindo enzimas que atuam sobre a parede celular ou sobre o citoplasma. A celulose pode ser decomposta até glicose, a lignina também pode ser decomposta, mas pouco se sabe sobre esta degradação, além da 
degradação de proteínas e hemiceluloses, amido, lipídeos, ácidos nuclêicos e outros componentes do citoplasma. Podem ser produzidas toxinas que podem interferir no metabolismo celular alterando sua permeabilidade e interferindo no processo de respiração da planta: a ação das toxinas resulta sempre na morte da célula e tecidos afetados; homônios como auxinas, giberelinas produzidas pelos patógenos irão interferir no desenvolvimento normal da planta. $O$ efeito desses mecanismos de ataque resultam sempre na hidrólise dos componentes celurares, sendo os produtos finais absorvidos pelo patógeno que os utiliza para seu crescimento (GALLI \& CARVALHO, 1978).

Da mesma forma que o patógeno possui um variado mecanismo de ação para colonização do hospedeiro, (GALLI \& CARVALHO, 1978) relatam que este pode apresentar diversas formas de resistência; defesas estruturais como por exemplo a formação de filoses, gomas nos espaços intercelulares, formação de celulas suberificadas que isolam o tecido afetado; e defesas bioquímicas, como presença de compostos fenólicos em concentrações tóxicas e inibidoras ao patógeno, que sobre a ação de várias enzimas se oxidam resultando na produção de tanino, lignina, quinona e outros componentes celulares. A hipersensibilidade também pode ser considerada um mecanismo de defesa da planta; é uma reação necrótica que se manifesta quando o citoplasma da celula invadida sofre necrose rápida impedindo o desenvolvimento do parasita ou se mostrando tóxico ao patógeno. Nesses casos, a necrose das células vizinhas aprisiona o patógeno e limita a infecção a uma área muito pequena.

\subsubsection{Podridão Vermelha}

A entrada da broca na cana-de-açúcar através de perfurações no colmo e construção de galerias, favorece a penetração de bactérias e de um fungo que encontra ali, um meio propício para seu desenvolvimento, causando a podridão vermelha do colmo que pode abranger toda a região compreendida entre as diversas galerias cavadas pela broca (ALMEIDA \& SOUZA, 1936). 
No Brasil, geralmente os relatos sobre a doença estão sempre associados aos danos da broca da cana Diatraea saccharalis, como é o trabalho de GALLO (1963), que atribuiu uma perda média em sacarose provável de $4,1 \%$ para uma média de $22,2 \%$ de intensidade de infestação da broca e também uma perda em peso médio de $4,8 \%$ com a mesma intensidade de infestação.

Ela se manifesta na folha e nos colmos da cana-de-açúcar, onde é facilmente visível em corte longitudinal; sobre o fundo vermelho aparecem manchas claras alongadas transversalmente. Este conjunto, parênquima vermelho com manchas claras constitui o sintoma típico da doença, podendo ter maior ou menor intensidade, dependendo da resistência vegetal. O Colletotrichum falcatum apresenta numerosas raças fisiológicas que diferem muito na sua patogenicidade. Condições de temperatura e umidade elevadas que favorecem a atividade da broca, facilitando a penetração do $C$. falcatum no interior dos colmos, concorrem para aumentar a incidência da doênça. Uma vez o colmo afetado, as condições de baixa umidade favorecem o desenvolvimento da doença (GALLI \& CARVALHO, 1978).

\subsubsection{Ciclo de doença}

Durante o período de crescimento da cana-de-açúcar, as infecções na nervura central produzem o inóculo necessário para a disseminação do patógeno. Estes esporos são dispersados pelos respingos da chuva ou por gotas de orvalho até os colmos ao redor do nó envolvido pela bainha foliar (SANGUINO, 1979).

Os esporos germinam e penetram através da cicatriz foliar e das gemas (STEIB \& SHILTON, 1951) ou através das perfurações feitas pela broca da cana-de-açúcar, Diatraea saccharalis (ABBOTT \& HUGHES, 1961).

O fungo pode permanecer de uma estação de crescimento para outra em soqueiras, restos da cultura e em toletes para o plantio (SANGUINO, 1979). 
Com o crescimento do micélio do fungo, o protoplasma das células da cana-deaçúcar se modificam e secretam uma substância gomosa nos espaços intercelulares; nesse mesmo tempo, uma substância vermelha é produzida e as paredes celulares a absorvem tomando então uma coloração avermelhada. Esta substância é antagônica ao fungo, o qual cresce pouco dentro dessa zona vermelha (EDGERTON, 1959). O mesmo autor cita que em variedades resistentes, a zona vermelha é formada muito rápidamente para conter as movimentações do fungo.

O grau de resistência de uma cana à podridão vermelha, é indicado pela rapidez com que esta zona vermelha é formada (EDGERTON \& CARVAJAL, 1944).

Os tecidos afetados pelo fungo que entrou no interior da cana-de-açúcar, quer por penetração através das bainhas foliares, quer por injúrias causadas por insetos, começam a desenvolver muitas características, ficando levemente ácidos e com odor afetado (ABBOTT \& HUGHES, 1961).

Muitos estudos têm sido realizados para avaliação da resistência da cana-deaçúcar frente à doença da podridão-vermelha, e os polifenóis têm sido considerados como tendo um importante papel na resistência à doença. Em seu trabalho VERMA et al., ABNT (1971) observaram que as variedades resistentes à doença são caracterizadas pela maior quantidade de polifenóis como ácido clorogênico e glicosídeos flavonas não identificados que são ausentes nas variedades susceptíveis.

\subsection{Prejuízos Causados pelo Complexo Broca/Podridões}

\subsubsection{Prejuízos de Ordem Agrícola}

ARAÚJO et al. (1984), conduziram um trabalho sobre o efeito do ataque da broca Diatraea saccharalis em canas destinadas ao plantio (NA 5679, CB 41-76 e CB 47$355)$, observando que, excluindo-se o aspecto visual das mudas, as perdas por canas mortas ou quebradas e a possível disseminação da praga do viveiro para o plantio, não houve 
nenhum problema quando se utilizou muda com elevada porcentagem de intensidade de infestação, não justificando porém, aumentar-se a quantidade desta por hectare. Ainda observaram uma tendência de o tratamento com alta intensidade de infestação apresentar uma melhor germinação. Possível explicação para este fato, pode estar no aumento dos açúcares redutores, ocasionado pelo ataque do complexo broca-podridões, atingindo níveis ótimos para induzir a germinação, que segundo DILLEWIJN (1952) provávelmente a estimulam.

STOLF et al. (1989), estudaram duas hipóteses explicativas para o fenômeno da diminuição do índice de infestação da broca da cana-de-açúcar (D. saccharalis), com o número de corte concluindo que, o fator condicionante desse fenômeno são variações das características anatômicas, morfológicas e químicas condicionadas pelo potencial de desenvolvimento da planta no decorrer dos cortes e não pelo desequilíbrio biológico causando durante as operações de reforma do canavial.

Em um experimento onde estudou-se a queima da cana-de-açúcar sobre a população da broca $D$. saccharalis (Fab, 1974), seus predadores e parasitas, concluiu-se que a queima praticada para a colheita e eliminação dos restos culturais reduziram drasticamente a população da broca, o mesmo não ocorrendo a seus inimigos naturais (DEGÁSPARI et al., 1983).

$\mathrm{O}$ ataque da broca prejudica o rendimento em peso de cana por unidade de área plantada. É evidente que os efeitos verificados dependem dentre outros fatores, fundamentalmente da intensidade do ataque que pode ocorrer de várias maneiras (VALSECHI et al., 1976):

- perfurações da cana em desenvolvimento onde ocorrerá redução do tamanho e da grossura dos gomos, os quais ao mesmo tempo, têm o seu teor de fibra aumentado (ALMEIDA \& SOUZA (1936); ELLIS et al., (1959); STUPIELLO \& MORAES, 1974); 
- $\quad$ destruição da "olhadura" da cana pela lagarta, provocando a morte do ápice vegetativo, causando a proliferação de rebentos laterais chamados espúrias, causando prejuízo do rendimento agrícola (GUAGLIUMI, 1972).

com a morte da gema apical, ocorre a morte das folhas centrais, deixando verdes as folhas laterais tendo-se então o chamado "coração morto" ("dead heart"). Isto, além de reduzir a tonelada de cana por área, exige custosos replantes (VALSECHI et al., 1976).

A literatura aponta a possibilidade da broca cavar galerias horizontais que facilitam o deitamento ou quebra do colmo.

MATHES et al. (1969), afirmam que quanto maior a porcentagem de entrenós brocados, maior a perda da quantidade de açúcar por acre de cana. Para uma infestação de $30 \%$ a perda de açúcar foi de aproximadamente 5500 libras por acre de cana, em um trabalho realizado em Louisiana.

Já no México, um trabalho realizado por RUIZ et al. (1968) durante as safras de 64,65 e 66 , constataram uma perda média de $0,725 \mathrm{Kg}$ de açúcar por tonelada de cana a cada $1 \%$ de infestação pela broca.

GALLO (1963), trabalhando com 3 variedades de cana em 5 diferentes locais do Estado de São Paulo, encontrou uma perda de peso de cana da ordem de 4,9\%, para as canas com brocas em relação às canas sadias, enquanto que SCARAMUZZA (1947), constatou uma perda de $40 \%$ em Cuba.

Segundo MATHES et al. (1960), a broca da cana-de-açúcar diminue o tamanho e o peso dos colmos, bem como a quantidade de caldo e aumentam a quantidade de gomas e não açúcares. Esta condição será mais agravadapela entrada dos fungos e bactérias dentro dos túneis, feitos pela broca. Tal injúria também reduz a qualidade de armazenamento de cana cortada para moagem. O tamanho e o peso dos colmos diminuem bem como a 
quantidade de caldo na cana. A alimentação da broca causa um aumento da quantidade de gomas e não açúcares indesejáveis no caldo e retarda a maturidade dos colmos afetados. Os túneis feitos pela broca facilitam a entrada de microrganismos, provocando doenças como a podridão vermelha (CHARPENTIER et al., 1965).

Estudos feitos por INGRAM (1946), em Houma, durante os anos de 19361939, com canas da mesma idade e com diferentes graus de infestação, observou-se um índice de $0,5 \%$ de perda de sacarose total para cada $1 \%$ de entrenós brocados, adicionando ainda uma perda devido à redução em peso da cana perfazendo um total de $0,75 \%$ de perda de sacarose total para cada $1 \%$ de entrenós brocados.

MATHES et al. (1960) mostraram que diferentes varidades de cana-de-açúcar têm diferentes perdas de sacarose para um mesmo grau de infestação, mas a média para todas as variedades foi por volta de $0,75 \%$ para cada $1 \%$ de entrenós brocados.

\subsubsection{Prejuízos de ordem tecnológica}

STUPIELLO \& MORAES (1974), analisando a variedade CB 41-76, com o objetivo de estimar algumas alteraçôes tecnológicas ocasionadas pelo processo broca/podridão vermelha, constataram que a pol e a fibra da cana são comprometidas por esse fator, bem como o rendimento industrial.

VAN DINE (1926), CRAWLEY (1929) e SCARAMUZZA (1947 e 1951) demonstraram que a broca de cana-de-açúcar causa perdas consideráveis em relação ao brix, sacarose, pureza e rendimento industrial.

McKAIG JUNIOR \& FORT (1936), realizaram um trabalho para avaliação da composição química do caldo de cana-de-açúcar afetado pela broca e pela podridão vermelha. Analisaram caldos provenientes de canas só afetadas pela broca, só afetadas pela podridão vermelha e afetadas por ambas, onde, as variedades analisadas foram POJ 213 e POJ 36, chegando as seguintes conclusões: 
- quando o caldo é extraído da cana afetada conjuntamente pela broca e pela podridão vermelha, os danos têm extensões maiores do que a broca sozinha. Em ambos os casos as mudanças na composição do caldo são:

- decréscimo na extração do caldo, a porcentagem de sólidos, a sacarose, as purezas aparente e real diminuem;

- a porcentagem de açúcares redutores, cinzas, gomas e não-açúcares orgânicos são significativamente aumentada;

- nitrogênio protéico e copostos de nitrogênio não protéico aumentam, aumentando assim o conteúdo de nitrogênio nos xaropes;

- nas cinzas, o potássio tem um aumento maior que os outros constituintes minerais;

- a cor e a turbidez dos caldos e dos xaropes clarificados aumentam consideravelmente.

Conclusões semelhantes foram encontradas no trabalho de INSTITUTO DE TECNOLOGIA DE ALIMENTOS (1974), onde determinou-se as perdas de sacarose na cana-de-açúcar, devidas ao ataque da broca e podridão vermelha. $\mathrm{O}$ brix, pol, pureza, fibra e sacarose da cana foram afetados negativamente: o $\mathrm{pH}$ foi muito pouco afetado, mesmo numa infestação relativamente alta; já a acidez foi sensivelmente alterada pela infestação da broca, principalmente acima de $10 \%$, notou-se també que a influência da infestação na acidez foi maior nas canas queimadas; houve aumento no teor de cinzas para canas infestadas e também um aumento no teor de goma.

As alterações tecnológicas da broca da cana-de-açúcar foram estudadas também por PRECETTI et al. (1988), em algumas variedades de cana-de-açúcar, amostrando entrenós brocados e não brocados em número proporcional, retirados do pé, meio e ponta 
de colmos com níveis de intensidade de infestação de $0,10,20,30,40,50 \%$. Verificou-se que houve redução de brix, pol, pureza, açúcar total, açúcar teórico recuperável, etanol provável, aumento de fibra, tendência de redução do volume de caldo extraído e tendência de aumento de açúcares redutores, com o aumento da intensidade de infestação pela broca. Os índices médios de perdas de açúcar e de álcool a cada $1 \%$ de intensidade de infestação foram de $0,370 \mathrm{Kg} / \mathrm{t}$ de cana e $0,1651 / \mathrm{t}$ de cana, respectivamente.

Em um trabalho realizado por ALMEIDA \& SOUZA (1936), foi observado que devido ao ataque da broca, a cana tinha um porcentagem maior de fibra, como conseqüência tinha menos caldo proveniente de canas brocadas era mais difícil e onerosa, e sua pureza era menor. A Tabela 2 mostra as diferenças entre uma amostra atacada pela broca e uma amostra sadia.

ELLIS et al. (1959) através de 15 experimentos chegaram às seguintes conclusões:

- decréscimo de pol e da pureza do caldo, também da extração do caldo \% de cana e um aumento na porcentagem de fibra;

- pelo exame de colmos essencilamente livres de brocas com canas brocadas, cuja média na intensidade de ataque foi de 20,17\% para 85 comparações, resultou uma queda de $0,854 \%$ no açúcar provável \% cana, sendo que $0,588 \%$ seriam devidos á diferença na composição do caldo e 0,266\% a um decréscimo na extração.

MATHES et al. (1969), estudaram os componentes das perdas pela broca; para isso, 105 parcelas, com dois níveis de infestação, $40 \%$ e 60\%, foram estudados. As diferenças destes valores resultou, na prática, a uma perda total de $2096,6 \mathrm{Kg}$ de açúcar/ha. Deste total, $74 \%$ foram perdidos no campo e o restante (26\%) na usina. Dos $74 \%, 54 \%$ foram causados pela diminuição do peso dos colmos e os $20 \%$ restantes, pela menor quantidade de colmos/área. 
Das perdas na usina $(26 \%), 14 \%$ foram causados pelo menor teor de sacarose, $3 \%$ pela queda na pureza do caldo e $9 \%$ pela redução da porcentagem de caldo extraído.

TABELA 2 - Diferenças entre amostras de cana-de-açúcar atacada pela broca e uma amostra sadia.

PARTE SADIA

Peso total $(\mathrm{Kg})$

100

100

Volume do caldo (l)

26,5

34,5

Brix peso

16,17

20,07

Brix volume

17,25

21,75

Densidade

1,0666

1,0838

Sacarose

13,40

18,60

Açúcar redutor

0,992

0,594

Acidez em SO (ml)

2,058

1,078

Acidez em $\mathrm{CaO}(\mathrm{ml})$

1,176

0,616

$\mathrm{pH}$

5,4

5,6

Pureza

86,51

92,68

Fonte: ALMEIDA \& SOUZA (1936)

Em 1975, SILVA \& CAMPOS, analisaram a influência do complexo brocapodridões na composição da cana-de-açúcar. $\mathrm{O}$ brix \% cana, pol\% cana, pureza, açúcares redutores e fibra\% cana, foram afetados negativamente; em relação ao $\mathrm{pH}$ não houve grandes diferenças, mas mesmo assim, os pHs das canas atacadas apresentaram-se ligeiramente menores, o que poderia indicar uma tendência maior de deteriorização 
segundo MEADE (1963), chegando às mesmas conclusões que VAN DINE (1926), CRAWLEY (1929), MCKAIG JUNIOR \& FORT (1936), SCARAMUZZA (1947), MATHES et al. (1960, 1969), entre outros. Encontraram uma perda de $3,09 \mathrm{Kg} / 100 \mathrm{Kg}$ de Pol para uma infestação de $10 \%$ concluíram que o ataque do complexo broca/podridões é altamente prejudicial pois além de diminuir o teor de sacarose, acarreta a diminuição da capacidade e da extração das moendas e conseqüentemente queda no rendimento industrial.

Experimentos realizados por SILVA et al. (1975) com o mesmo complexo, causaram danos apreciáveis à agroindústria; com o aumento da intensidade da infestação, houve diminuição da sacarose e pol\% cana, pureza e pH aumento no teor de açúcares redutores, gomas, acidez e cinzas, comprometendo sua composição tecnológica.

Perdas de sacarose em caldo de canas atacadas pela broca são atribuídas às fermentações e inversões produzidas por fungos e bactérias dentro das galerias abertas pelas brocas. No trabalho de BARRETO (1954), foi constatado que a cada $1 \%$ de aumento de infestação pela broca, havia uma redução na ordem de $0,02329 \%$ de sacarose na cana-deaçúcar.

Deve-se salientar que a intensidade da infestação pela broca sempre está correlacionada com as perdas em açúcar, porém observando os trabalhos, onde foram feitas essas correlações, nota-se que há muitas variações, devido principalmente ao material examinado (variedade e idade da cana-de-açúcar e localização da infestação). Por outro lado essa correlação não pode ser uma relação aritmética e sim exponencial, onde a perda é cada vez maior, quanto mais alta for a infestação. A Figura 1 mostra a redução da \% de açúcar provável em relação a intensidade de infestação, estudada por vários autores. Estes índices são ainda imperfeitos porque muitas vezes não consideram as perdas totais causadas especialmente pelos altos níveis de infestação no campo (TERAN, 1980). 


\subsubsection{Efeitos sobre a fermentação etanólica}

A cana-de-açúcar possui uma microflora epífita e ainda bactérias do solo que aproveitando o orifício aberto pela broca, invadem o interior do colmo encontrando aí um meio propício para seu desenvolvimento.

Dentre as bactérias descritas como constituintes da microflora da cana-deaçúcar as mais comuns são os Leuconostoc, Lactobacillus, Bacillus subtilis, Aerobacter sp e Enterobacter (DULCAN \& COLMER, 1964).

Os microrganismos irão metabolizar os açúcares produzindo ácidos como lático, málico e acético (BEVAN \& BOND, 1971).

Em determinadas concentrações esses produtos podem agir como inibidores da fermentação alcóolica ou em baixas concentrações podem estimular o metabolismo celular aumentando o rendimento fermentativo (MAIORELLA et al., 1983).

LOPES et al. (1983) realizaram fermentações, utilizando-se de cana planta da variedade NA 56-79, com 2 níveis de intensidade de infestação pela broca Diatraea saccharalis (alto e baixo), demonstrando que, sob as condições que se conduziu o experimento para cada $1 \%$ de Intensidade de Infestação da broca, Diatraea saccharalis, estimou-se uma perda de 62 litros de álcool por hectare. Os resultados também evidenciaram que a intensidade de infestação pode influenciar a qualidade da matéria-prima, principalmente por diminuir o teor de sacarose e por aumentar a porcentagem de açúcares redutores. Também revelaram que o caldo proveniente das canas com baixa intensidade de infestação apresentaram maior rendimento de fermentação alcóolica, maior quantidade de pol e litros de álcool por hectare em relação ao caldo com alta intensidade de infestação. 

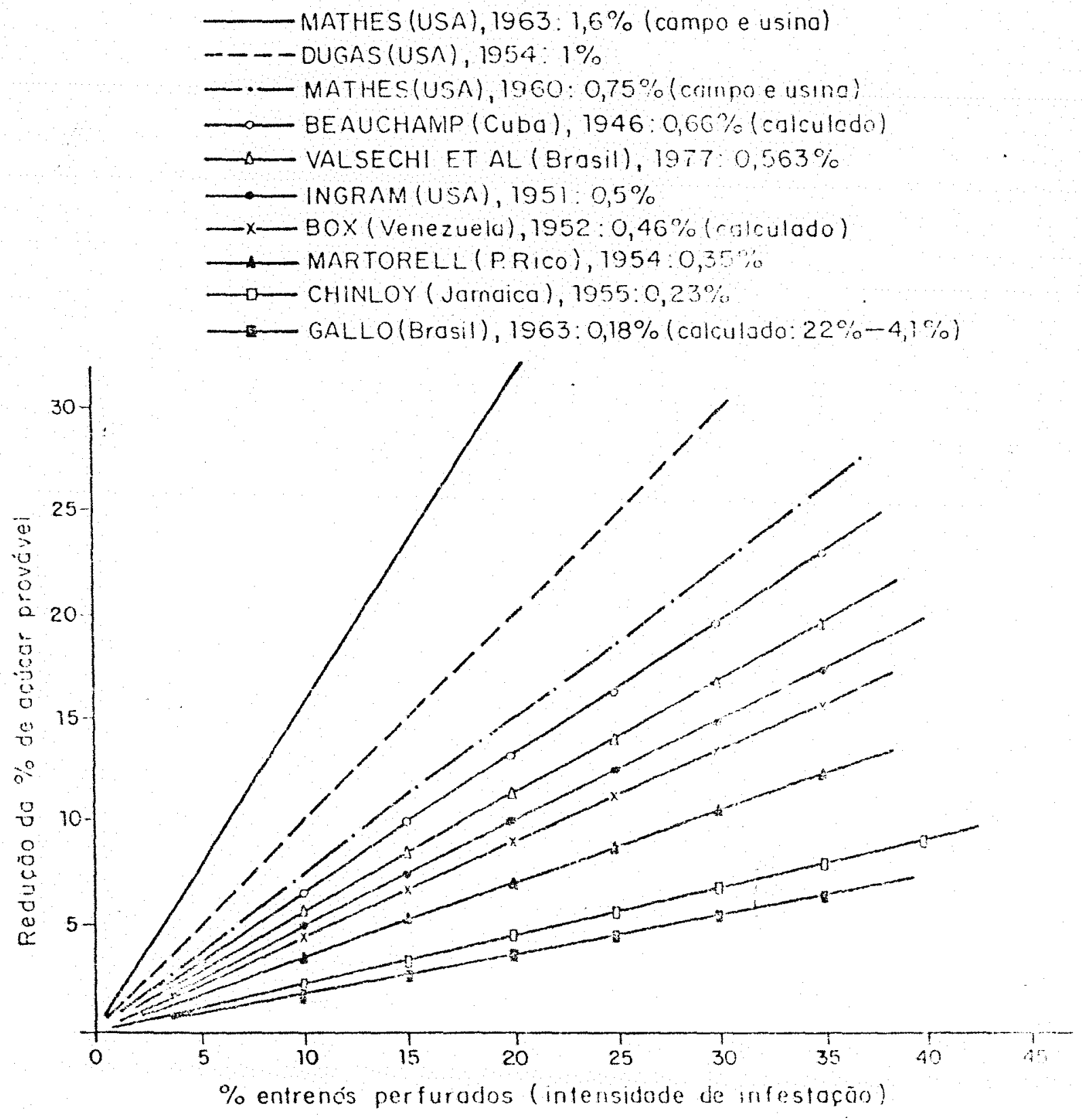

Figura 1 - Redução da porcentagem de açúcar provável em relação à intensidade de infestação. (Fonte: TERAN, 1980). 


\subsection{Critérios de Avaliação da Infestação da Broca da Cana-de-Açúcar}

GALLO (1963) observa que não se deve confundir Infestação com Intensidade de Infestação.

$$
\begin{gathered}
\text { Infestação }=\frac{n^{\circ} \text { de colmos brocados }}{n^{\circ} \text { total de colmos examinados }} \times 100 \\
\text { Intensidade de Infestação }=\frac{n^{\circ} \text { de internódios brocados }}{n^{\circ} \text { de internódios examinados }} \times 100
\end{gathered}
$$

Segundo o autor, a infestação deve ser estimada numa amostra de no mínimo 100 colmos colhidas ao acaso. Mesmo assim, trata-se de uma avaliação imperfeita, uma vez que não leva em conta o número de perfurações nas canas examinadas. Já a intensidade de infestação dá uma idéia mais exata do ataque, pois que, neste caso, leva-se em consideração o número de internódios brocados contra o número total examinado.

Segundo GUAGLIUMI (1972), internacionalmente é habitual classificar-se o grau de ataque da broca conforme Tabela 3.

Segundo SANGUINO (1979), pode-se calcular o Índice Volumétrico de Doença (IVD), levando em consideração o comprimento total do colmo, diâmetro médio do colmo, comprimento da lesão e diâmetro médio da lesão, onde:

$$
I V D=\frac{\text { Vol. do colmo doente }}{\text { Vol. do colmo total }} \times 100
$$

A Tabela 4 mostra o IVD e a classe da resistência para a cana-de-açúcar. 
Tabela 3 - Grau de ataque da broca conforme a Infestação.

Infestação Intensidade de Infestação Grau de Infestação

\begin{tabular}{lcl}
\hline $0-25 \%$ & $0-5 \%$ & Baixo \\
$26-50 \%$ & $6-10 \%$ & Moderado \\
$51-75 \%$ & $11-15 \%$ & Regular \\
$76-95 \%$ & $16-25 \%$ & Elevado \\
$96-100 \%$ & $>26 \%$ & Muito elevado \\
\hline
\end{tabular}

Fonte: GUAGLIUMI, 1972.

TABELA 4 - IVD e resistência da cana-de-açúcar

IVD

$0,0-0,5$

$0,6-2,0$

$2,1-3,5$

$3,6-5,0$

$5,1-9,0$

$9,1-12,0$

$12,1-15,0$

$15,1-20,0$

$>20,0$
CLASSE DE RESISTÊNCIA

Altamente Resistente

Resistente

Resistente

Moderadamente Resistente

Moderadamente Resistente

Moderadamente Resistente

Suscetível

Suscetível

Altamente Suscetível

Fonte: SANGUINO (1979). 


\section{MATERIAL E MÉTODOS}

\subsection{Material}

- matéria-prima: caldo proveniente da cana-de-açúcar, variedade SP 71-1406, colhida manualmente no campo da Usina Piloto do Departamento de Ciência e Tecnologia Agroindustrial-ESALQ/USP, no $4^{\circ}$ corte sem queima prévia e despontadas; uma das variedades mais cultivadas nesta região, portanto, de considerável importância agrícola. Entre suas características publicadas no artigo VARIEDADES DA CANA-DE-AÇÚCAR E SUA IMPLICAÇÃO NA LAVOURA CANAVIEIRA (1989), destacam-se sua boa produtividade em açúcar, raro florescimento na região centro-sul e exigências nutricionais medianas, sendo moderameante resistente ao ataque do complexo broca-podridão.

- inóculo: fermento prensado tipo Fleischmann - Saccharomyces sp.

- fermentadores: projeto desenvolvido no Departamento de Ciência e Tecnologia Agroindustrial-ESALQ/USP de capacidade de 3 litros e volume útil de 2,5 litros, dotado de agitador eletromagnético, sistema de resfriamento/aquecimento, com tomada de amostras e saída de gases.

\subsection{Métodos}

- $\quad$ Açúcares Totais (AT) - dosado pelo método de LANE \& EYNON (1923), para o caldo (mosto).

- Açúcares Residuais (ARR) - dosado pelo método de Sommogyi \& Nelson, segundo NEISH (1952), para o vinho delevurado. 
- Brix - determinação do brix refratométrio. (ICUMSA, 1979).

- Teor Alcoólico - densimetria com prévia separação do álcool por destilação segundo AMORIM et al. (1979).

- Acidez Volátil - titulometria, utilizando hidróxido de sódio $0,02 \mathrm{~N}$ em potenciômetro até viragem da fenolftaleína, $\mathrm{pH} 8,2$.

- $\quad$ pH - determinação por potenciometria.

- Viabilidade, Brotamento Celular e Células/ml - nos vinhos levedurados, no leite de leveduras e no fermento tratado foram determinadas a viabilidade celular (\%), número de leveduras (células por mililitro) e brotamento (\%). As análises microbiológicas foram realizadas em microscópiocom Câmara de Newbauer. A porcentagem de células mortas foi avaliada por coloração com azul de metileno e citrato de sódio, com posterior contagem ao microscópio, segundo COPERSÚCAR (1987).

\subsection{Cálculo do Índice Volumétrico da Doença (IVD)}

$$
\text { IVD }(\%)=\frac{\text { volume total da doença }}{\text { volume total da cana }} \times 100
$$

O cálculo do IVD expressa a relação entre o volume total do complexo (broca/podridão) e o volume total do colmo, fazendo-se posteriormente a média ponderada de todos os colmos, segundo SANGUINEO (1979).

\subsection{Cálculo da Eficiência de Fermentação}

O cálculo da eficiência da fermentação expressa a relação entre o álcool produzido (ml) e o açúcar consumido (g), em comparação ao rendimento teórico de GayLussac, através do cálculo estequiométrico. 


$$
\eta=\frac{{ }^{\circ} G L_{\text {dorna }} \cdot \text { Volume }-{ }^{\circ} G L_{\text {cuba }} \cdot \text { Volume }}{C_{A T} \times 11.3313}=\%
$$

tanto para o mosto sadio como para o mosto contaminado pelo complexo broca-podridões, onde:

$\eta=$ eficiência de fermentação

${ }^{\circ} \mathrm{GL}_{\text {dorna }}=$ grau alcoólico na dorna de fermentação $(\mathrm{ml} / 100 \mathrm{ml})$

${ }^{\circ} \mathrm{GL}_{\text {cuba }}=$ grau alcoólico da cuba $(\mathrm{ml} / 100 \mathrm{ml})$

$\mathrm{C}_{\mathrm{AT}}=$ concentração Açúcares Totais no mosto $(\mathrm{g} / 100 \mathrm{ml})$

\subsection{Cálculo da Produtividade de Fermentação}

Calculada mediante a relação de álcool produzido por volume e por hora.

$$
\rho=\frac{\left({ }^{\circ} G L_{\text {dorna }} / 100 . \text { Volume }(m l)-{ }^{\circ} G L_{\text {cuba }} / 100 . \text { Volume }(m l)\right) \cdot 0,79432}{\text { Volume Total }(l) . \text { Hora Total de Fermentaçẫo }}=g
$$

Expressão válida para ambos os tratamentos, onde:

$\rho=$ produtividade da fermentação

${ }^{\circ} \mathrm{GL}_{\text {doma }}=$ grau alcoólico na dorna de fermentação $(\mathrm{ml} / 100 \mathrm{ml})$

${ }^{\circ} \mathrm{GL}_{\text {cuba }}=$ grau alcoólico da cuba $(\mathrm{ml} / 100 \mathrm{ml})$ 


\subsection{Condições Operacionais}

- Temperatura de fermentação $=33 \pm 1{ }^{\circ} \mathrm{C}$

- $\%$ fermento $\quad=30 \%$ do volume total

- Açúcares totais no mosto $=16-18,5 \%$

- Brix do mosto = $\quad 16,0-20,0$ Brix

- $\mathrm{pH}$ durante a fermentação $=3,6-4,0$

- Teor alcoólico $\quad=6,0-9,0^{\circ} \mathrm{GL}$

- Índice voumétrico de doença (IVD) $=3-8 \%$

- Agitação $\quad \approx 60 \mathrm{rpm}$

- $\mathrm{pH}$ do fermento $\quad=2,5-2,8$

\subsection{Procedimento Experimental}

As canas, chegando ao laboratório, eram limpas e separadas em dois feixes; um contendo só canas sadias, sem nenhuma perfuração ou podridão e outro composto por canas que apresentavam perfurações da broca.

Depois dos feixes separados, os colmos que continham as perfurações eram abertos longitudinalmente com o auxílio de serra elétrica circular, para se constatar a presença da broca e das podridões, e também para o cálculo do IVD (Índice Volumétrico de Doença), que tem como parâmetros o comprimento total do colmo, diâmetro médio do colmo, comprimento da lesão e diâmetro médio da lesão (SANGUINO, 1979), onde o diâmetro era medido em três regiões diferentes, considerando o colmo um cilindro perfeito. 
O processo de fermentação etanólica foi de batelada em fermentadores fechados, utilizando caldo de cana como mosto. Foram realizadas dez fermentações com 3 ciclos consecutivos, tendo-se o fermentador testemunha (mosto sadio) e outro com o mosto contaminado pelo complexo broca/podridão, com o IVD obtido a partir do cálculo na matéria-prima conforme ítem 3.3 .

Para cada fermentação foram analisados os seguintes parâmetros:

- caldo (mosto): pH, acidez volátil, açúcares totais e brix

- vinho: pH, acidez volátil, açúcar total, açúcar residual, teor alcóolico, viabilidade celular, brotamento celular e células por mililitro no início $\left(\mathrm{H}_{\mathrm{i}}\right)$ e no final da fermentação $\left(\mathrm{H}_{\mathrm{f}}\right)$.

Depois de uma hora de cessado o desprendimento de $\mathrm{CO}_{2}$ nos fermentadores, a fermentação era dada como completada.

\subsubsection{Preparo do Inóculo}

Foi estabelecida uma porcentagem de células de $10 \%$ em relação ao volume total da dorna, ou $30 \%$ do volume total, sendo este procedimento geralmente utilizado pelas destilarias.

Foram pesados $225 \mathrm{~g}$ de fermento prensado e adicionado água destilada a $30^{\circ} \mathrm{C}$ até $750 \mathrm{ml}$. Em seguida, fez-se o tratamento com ácido sulfúrico concentrado p.a. até pH 2,5 - 2,8 antes de dar início às fermentações.

No fermento foram feitas as análises de viabilidade e brotamento celular e células

por mililitro para a primeira fermentação, para os dois ciclos seguintes além dessas já citadas, era feito também o teor alcóolico a fim de calcular o rendimento da eficiência fermentativa. 


\subsubsection{Preparo do Mosto}

O mosto foi obtido a partir do caldo da cana-de-açúcar da variedade SP 71-1406, colhida manualmente sem despalha a fogo. Os dois feixes, o da cana sadia e o da cana atacada pelo complexo eram moídos separadamente a conservados sob refrigeração a $5^{\circ} \mathrm{C}$ até o momento do seu uso para os ciclos fermentativos seguintes. Para cada ciclo de fermentação foram utilizados 1750 mililitros de mosto. O teor de açúcar total no mosto variou de $17,85 \mathrm{~g} / 100 \mathrm{ml} \mathrm{a} 19,68 \mathrm{~g} / 100 \mathrm{ml}$; portanto, não houve correção do brix e do Açúcar total contido no meio.

\subsubsection{Recuperação das Células}

Terminada a primeira fermentação, as células de levedura foram recuperadas e tratadas para início do ciclo seguinte. Para tanto, o volume total de vinho foi totalmente centrifugado a $1500 \mathrm{~g}$ para separação do vinho, do leite de levedura. Este procedimento foi válido para os dois fermentadores.

Com o vinho delevurado foram analisados a acidez volátil e açúcar residual.

O leite de levedura foi recuperado utilizando o próprio vinho delevurado e água destilada até completar o volume necessário para o fermento, $750 \mathrm{ml}$ ou seja, $375 \mathrm{ml}$ de leite (células + vinho) e $375 \mathrm{ml}$ de água; foi feito o tratamento com ácido sulfúrico até $\mathrm{pH}$ $2,5-2,8$, deixando em agitação por uma hora, para início do ciclo seguinte.

Viabilidade, brotamento, células por mililitro e teor alcóolico foram analisados no fermento tratado.

\subsection{Descrição de um Ensaio Típico}

Os mostos previamente preparados eram colocados nas dornas juntamente com o inóculo, também previamente preparado. 
As fermentações eram conduzidas com agitação constante e temperatura controlada.

No início e no final das fermentações eram coletadas amostras das duas dornas para as determinações analíticas.

No final de cada fermentação fazia-se a recuperação do fermento, conforme o ítem 3.7.3., para início de outra fermentação, conforme Figura 2. 


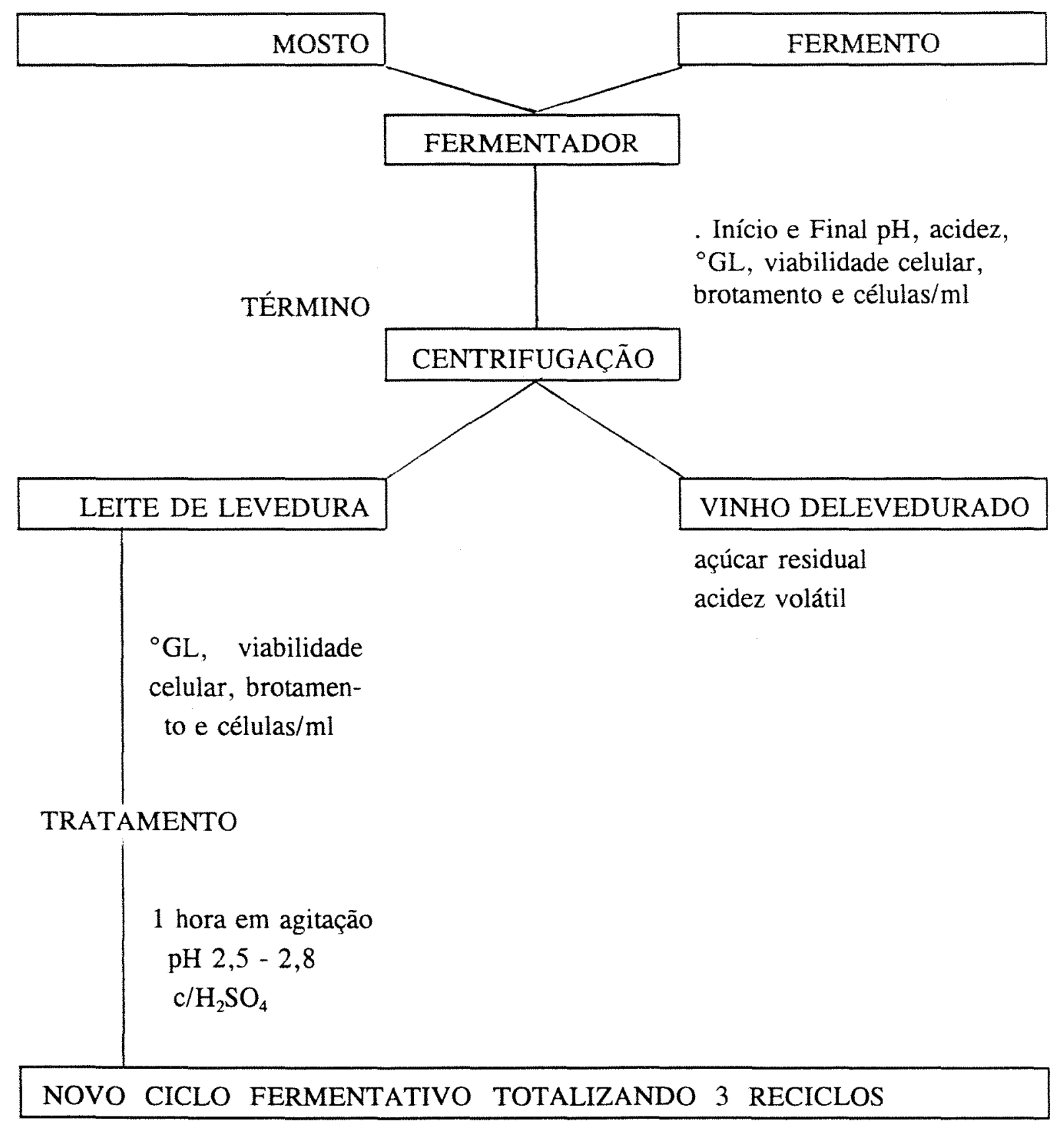

PROCEDIMENTO VÁlido TANTO PARA O MOSTO SADIO COMO PARA O MOSTO CONTAMINADO

Figura 2 - Esquema de um ensaio típico. 


\section{RESULTADOS E DISCUSSÃO}

\subsection{Cálculo do índice volumétrico de doença (IVD) nas canas atacadas pelo complexo broca-podridão}

A Tabela 5 mostra o volume da cana e o volume da doença $\mathrm{em} \mathrm{cm}^{3}$, bem como a relação entre eles resultando no IVD dado em porcentagem. Os colmos foram colhidos no $4^{\circ}$ corte, no campo da Usina Piloto do Departamento de Ciência e Tecnologia Agroindustrial da ESALQ/USP. Moeu-se o necessário de colmo sadio atacado para a fermentação e mais os dois ciclos subseqüentes.

Tabela 5 - Resultados médios obtidos para IVD a partir da variedade SP 71-1406 no ano de 1991.

\begin{tabular}{cccc}
\hline \hline Ensaios & $\begin{array}{c}\text { Volume Total da Cana } \\
\left(\mathrm{cm}^{3}\right)\end{array}$ & $\begin{array}{c}\text { Volume Doença } \\
\left(\mathrm{cm}^{3}\right)\end{array}$ & $\begin{array}{c}\text { IVD } \\
(\%)\end{array}$ \\
\hline 1 & $13.596,08$ & 387,15 & 2,85 \\
2 & $13.073,85$ & 411,27 & 3,15 \\
3 & $7.896,35$ & 256,35 & 3,26 \\
4 & $13.215,08$ & 669,87 & 5,07 \\
5 & $4.190,98$ & 331,74 & 7,92 \\
6 & $5.382,10$ & 430,57 & 8,00 \\
7 & $10.235,15$ & 822,23 & 8,03 \\
8 & $16.709,68$ & $1.341,67$ & 8,03 \\
9 & $15.617,06$ & $1.265,68$ & 8,10 \\
10 & $18.029,37$ & $1.476,06$ & 8,19 \\
\hline \hline
\end{tabular}


Foi observado durante a colheita de cana que nos meses de outubro e novembro de 1991, (ensaios 8, 9 e 10) os colmos se apresentaram mais deteriorados pelo complexo, do que nos ensaios anteriores ( 1 a 5), onde a cana foi colhida nos meses de maio, junho, julho e agosto, estão mais fria e seca. Esse fato pode estar associado ao maior número de gerações de broca e a ação mais intensa dos microrganismos na estação mais quente, pois nesses meses (outubro e novembro) associa-se o calor com a umidade do ar, que é mais alta. É importante citar que GALLI \& CARVALHO (1978) observaram que condições de temperatura e umidade elevadas favorecem a atividade da broca, facilitando a penetração do C.falcatum no interior dos colmos, aumentando a incidência da doença, o que coincidiu com o observado durante o experimento.

\subsection{Análises do caldo extraído}

\subsubsection{Brix e Açúcar Total}

Sabendo que a cana amostrada para o experimento era da mesma variedade SP 71-1406, mesma idade, mesmas condições de plantio, deveria apresentar características semelhantes em relação ao brix, açúcar total, acidez e pH. Como foi observafo em trabalhos anteriores, esses parâmetros além de outros como a pol, pureza, açúcares redutores e etanol provável, podem sofrer alteraçōes quando a cana se encontra atacada pelo complexo broca/podridão vermelha como citam os trabalhos de VAN DINE (1926), CRAWLEY (1929), ALMEIDA \& SOUZA (1936), SCARAMUZZA (1947), MATHES et al. (1959), STUPIELLO \& MORAES (1974) E PERCETTI et al. (1988).

A Tabela 6 confirma os trabalhos já realizados, mostrando no caldo extraído a diminuição do brix, do açúcar total e também da tendência da diminuição do $\mathrm{pH}$ e aumento da acidez volátil para o caldo da amostra brocada com os respectivos I.V.D. Pode-se observar que os valores de $\mathrm{pH}$ no caldo contaminado foram decrescendo à medida que se aumentava o I.V.D. Este decréscimo do $\mathrm{pH}$ pode estar associado à deterioração do caldo pelos microrganismos que invadiram o interior do colmo depois da broca ter facilitado as 
suas penetrações, pois ácidos orgânicos como lático, málico e acético são produtos do metabolismo dos microrganismos como citam BEVAN \& BOND (1971) e MAIORELLA et al., 1983).

Relacionando a média de açúcares totais dos dez ensaios (Tabela 6) entre o caldo sadio e o caldo contaminado (média ponderada), pode-se observar que os colmos infestados com IVD variando de 4 a $8 \%$ apresentaram um teor de açúcar total 1,64\% menor, o que leva a uma diminuição do álcool teórico em 1,64\%, em relação ao Rendimento Teórico de Gay-Lussac (100 g flicose - 64,75 ml de etanol).

CS $\quad$ AT $=18,87 \mathrm{~g} / 100 \mathrm{ml}=330,225 \mathrm{~g} / 1750 \mathrm{ml}$ mosto

$\mathrm{CC} \quad \mathrm{AT}=18,56 \mathrm{~g} / 100 \mathrm{ml}=324,800 \mathrm{~g} / 1750 \mathrm{ml}$ mosto

Álcool Teórico CS $=213,821 \mathrm{ml}$

Álcool teórico $\mathrm{CC}=210,308 \mathrm{ml}$

$\%$ perda $=1,64 \%$

As figuras 3, 4, 5 e 6 mostram os resultados obtidos para o caldo sadio e o contaminado com seus respectivos IVD.

A figura 3 mostra que o brix do colmo do caldo contaminado foi sempre menor que o brix do colmo do caldo sadio. Como o brix mantém uma correlação estreita com o conteúdo de açúcares existentes do caldo, pode-se deduzir que conseqüentemente ocorre uma diminuição do açúcar total presente para o caldo contaminado na faixa estudada de IVD. Isto é melhor visualizado na Figura 4 onde, pode-se notar a menor concentração de açúcar total no caldo contaminado, exceção dos ensaios 1, 2, 3 e 4 onde o IVD foi menor que $8 \%$. Essa diminuição do açúcar total pode ter acontecido, devido ao maior ataque de microrganismos, que se utilizaram desses açúcares para seu metabolismo, transformando-os em ácidos orgânicos (BEVAN \& BOND, 1971). 
Tabela 6 - Brix, Açúcar Total, acidez volátil e pH do caldo sadio e do caldo contaminado com os respectivos I.V.D.

\begin{tabular}{|c|c|c|c|c|c|c|c|c|c|}
\hline \multirow{2}{*}{$\begin{array}{c}\text { Ensaio } \\
\text { (ordem cronologica } \\
\text { de colheita) }\end{array}$} & \multicolumn{5}{|c|}{ CALDO SADIO } & \multicolumn{4}{|c|}{ CALDO CONTAMINADO } \\
\hline & Brix & $\begin{array}{l}\text { Açúcar Total } \\
(\mathrm{g} / 100 \mathrm{ml})\end{array}$ & $\begin{array}{l}\text { Ac. Volátil } \\
(\mathrm{mg} / 100 \mathrm{ml})\end{array}$ & $\mathrm{pH}$ & $\begin{array}{l}\text { IVD } \\
(\%)\end{array}$ & Brix & $\begin{array}{l}\text { Açúcar Total } \\
\text { (g/100 ml) }\end{array}$ & $\begin{array}{l}\text { Ac. Volátil } \\
(\mathrm{mg} / 100 \mathrm{ml})\end{array}$ & $\mathrm{pH}$ \\
\hline 1 & 19,6 & 19,14 & 0,466 & 5,35 & 2,85 & 19,5 & 19,01 & 0,466 & 5,30 \\
\hline 2 & 18,4 & 17,85 & 0,456 & 5,28 & 3,15 & 18,4 & 17,81 & 0,458 & 5,26 \\
\hline 3 & 19,2 & 19,55 & 0,698 & 5,26 & 3,26 & 19,0 & 19,48 & 0,700 & 5,30 \\
\hline 4 & 18,6 & 18,09 & 0,559 & 5,19 & 5,07 & 18,0 & 18,15 & 0,560 & 5,05 \\
\hline 5 & 20,1 & 19,48 & 0,574 & 5,10 & 7,92 & 19,5 & 19,14 & 0,583 & 5,06 \\
\hline 6 & 17,9 & 17,71 & 0,613 & 5,30 & 8,00 & 17,5 & 17,69 & 0,618 & 5,27 \\
\hline 7 & 19,9 & 19,68 & 0,534 & 5,18 & 8,03 & 19,1 & 18,88 & 0,613 & 5,12 \\
\hline 8 & 19,3 & 18,82 & 1,12 & 5,10 & 8,03 & 18,7 & 18,51 & 1,40 & 4,99 \\
\hline 9 & 20,1 & 19,55 & 1,21 & 4,96 & 8,10 & 18,8 & 19,00 & 1,25 & 4,94 \\
\hline 10 & 19,0 & 18,88 & 1,02 & 5,17 & 8,19 & 18,2 & 18,15 & 1,40 & 4,94 \\
\hline Média & 19,21 & 18,87 & 0,733 & 5,19 & $\because$ & 18,63 & 18,56 & 0,874 & 5,09 \\
\hline
\end{tabular}




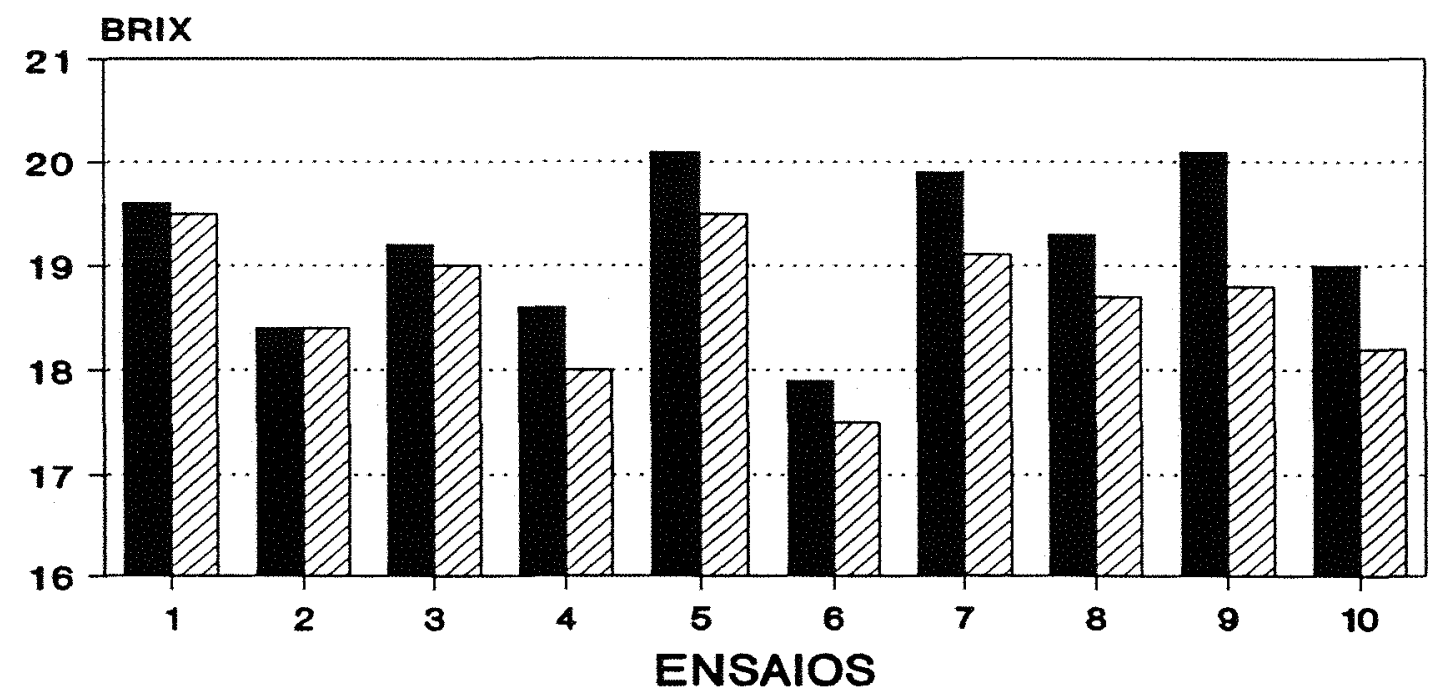

Brix Caldo sadio $Q Z$ Brix Caldo contaminado

Figura 3 - Resultados Médios do Brix do caldo sadio e do caldo contaminado. 


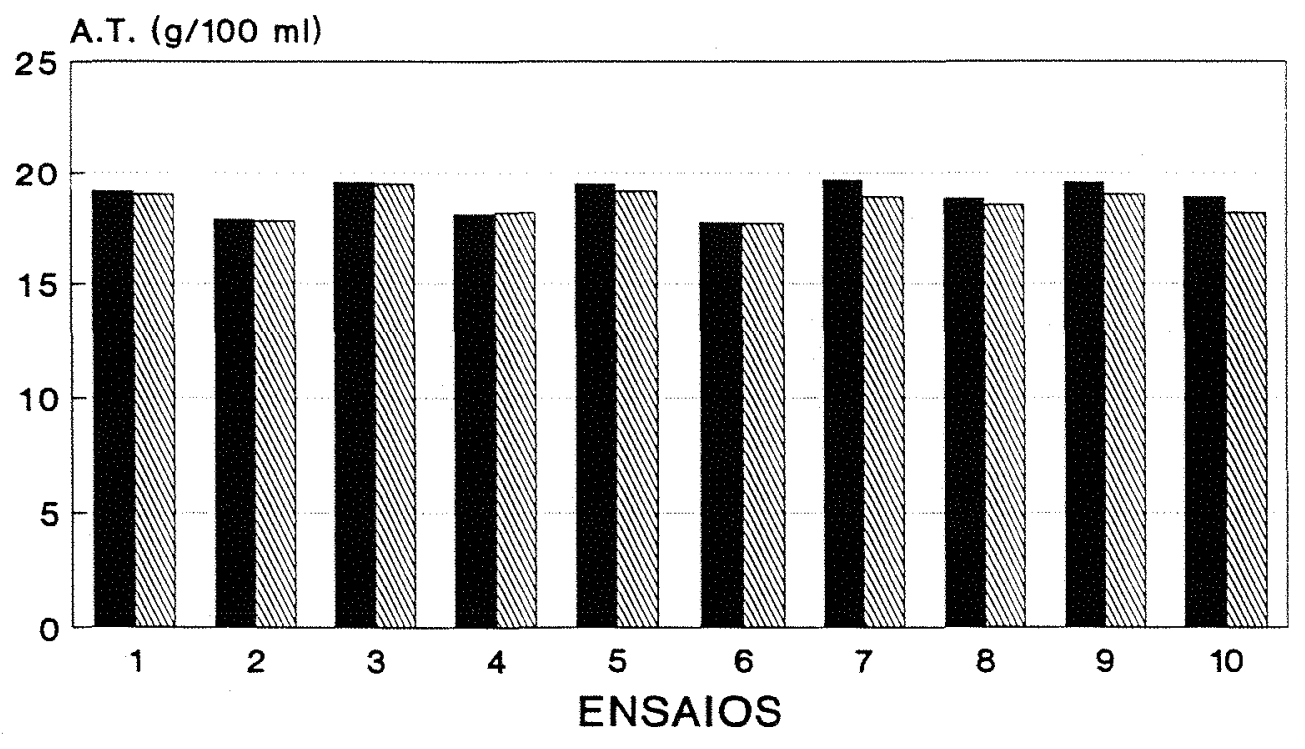

A.T. caldo sadio A.T. caldo contam.

Figura 4 - Resultados Médios dos Açúcares Totais do caldo sadio e do caldo contaminado. 


\subsubsection{Acidez volátil e pH}

Em relação à acidez, a Figura 5 apresenta os resultados obtidos durante o experimento; pode-se observar a tendência do aumento da acidez no caldo contaminado, principalmente quando o IVD atingiu valores em torno de $8 \%$. (ensaios $6,7,8,9$ e 10). Esta acidez pode ser um indicativo de deterioração no caldo contaminado pelo complexo broca/podridão vermelha, que tem além da broca da cana-de-açúcar, os microrganismos que os invadem pelo orifício aberto, por elas, utilizando-se dos açúcares para seu desenvolvimento e formando ácidos, aumentando portanto a acidez.

Observando a Figura 6, nota-se que o pH não foi um parametro ideal, para se avaliar as condições do caldo. Mesmo assim, o pH do caldo contaminado foi menor em relação ao sadio, o que está de acordo com os trabalhos do INSTITUTO DE TECNOLOGIA DE ALIMENTOS (1974) e de SILVA \& CAMPOS (1975) onde concluiram que o pH não foi um parâmetro sensível para a avaliação da deterioração do caldo, consequente do ataque complexo broca-podridão.

\subsection{Tempo de Fermentação}

No decorrer de todo o experimento foi observado que o $1^{\circ}$ ciclo de todos os ensaios apresentou um tempo menor de fermentação, tanto para o mosto sadio como para o mosto contaminado, variando de $4,20 \mathrm{~h}$ à $7,10 \mathrm{~h}$ para ambos os casos, sendo que para o menor tempo, o A.T. do mosto sadio foi de $17,71 \mathrm{~g} / 100 \mathrm{ml}$, e do mosto contaminado $17,69 \mathrm{~g} / 100 \mathrm{ml}$; e para o tempo de 7,10 horas o A.T. do mosto sadio foi $18,82 \mathrm{~g} / 100 \mathrm{ml}$ e $18,51 \mathrm{~g} / 100 \mathrm{ml}$ para o mosto contaminado, conforme Tabela 7 . A relação entre o tempo de fermentação do mosto "sadio" e do mosto "contaminado" pelo complexo broca/ podridões não apresentou diferenças significativas. 


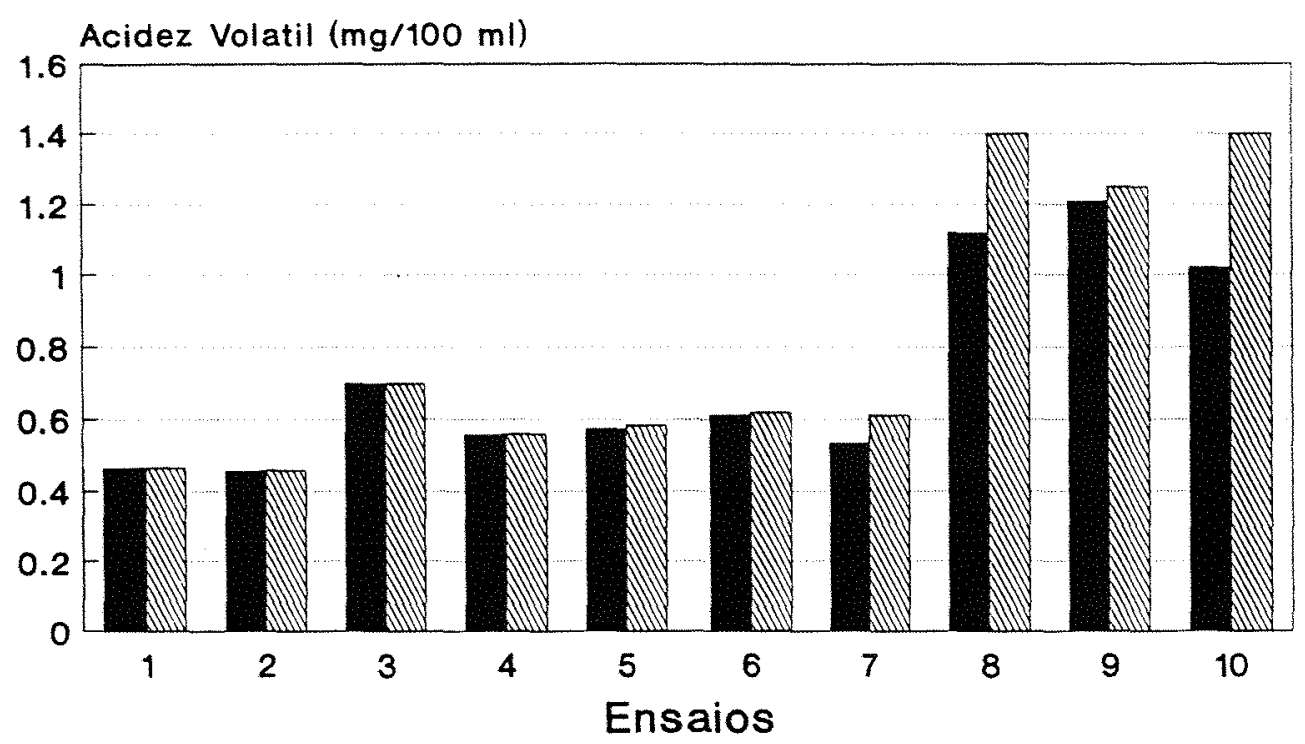

Acidez Caldo sadio $\$$ Acidez Caldo contam.

Figura 5 - Resultados médios da Acidez Volátil $(\mathrm{mg} / 100 \mathrm{ml})$ do caldo sadio e do caldo contaminado. 


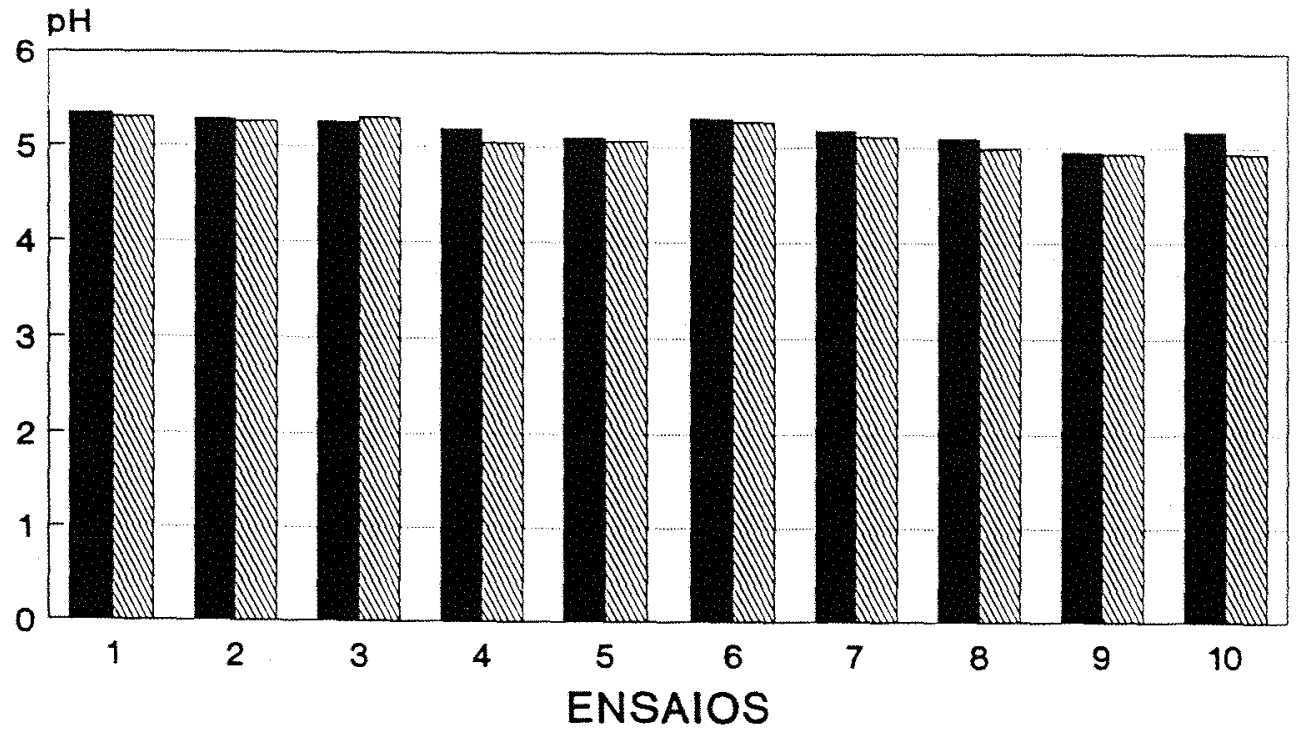

DH Caldo sadio $\mathrm{pH}$ Caldo contaminado

Figura 6 - Resultados médios do $\mathrm{pH}$ do caldo sadio e do caldo contaminado. 
Tabela 7 - Tempo de Fermentação em Horas.

\begin{tabular}{|c|c|c|c|c|c|c|}
\hline \multirow{2}{*}{$\begin{array}{l}\text { Ciclos } \\
\text { Ensaio }\end{array}$} & \multicolumn{2}{|c|}{$1^{\circ}$} & \multicolumn{2}{|c|}{$2^{\circ}$} & \multicolumn{2}{|c|}{$3^{\circ}$} \\
\hline & CS & $\mathrm{CC}$ & CS & $\mathrm{CC}$ & CS & $\mathrm{CC}$ \\
\hline 1 & 5,00 & 5,00 & 8,55 & 8,55 & 7,30 & 7,30 \\
\hline 2 & 6,30 & 6,30 & - & - & - & - \\
\hline 3 & 6,00 & 6,00 & 9,27 & 9,10 & - & - \\
\hline 4 & 5,15 & 5,15 & 10,00 & 9,55 & 9,20 & 9,20 \\
\hline 5 & 5,25 & 5,25 & 8,10 & 8,10 & 8,10 & 8,10 \\
\hline 6 & 4,20 & 4,20 & 8,35 & 8,35 & 8,15 & 8,15 \\
\hline 7 & 5,50 & 5,50 & 8,20 & 8,20 & 9,10 & 9,05 \\
\hline 8 & 7,10 & 7,10 & 7,50 & 7,50 & 7,20 & 7,20 \\
\hline 9 & 6,25 & 6,15 & 9,00 & 9,00 & 8,20 & 8,20 \\
\hline 10 & 6,15 & 6,15 & 8,25 & 8,25 & 8,15 & 8,15 \\
\hline
\end{tabular}

OBS: Os $2^{\circ}$ e $3^{\circ}$ ensaios não tiveram seus ciclos completados, devido à falta de energia elétrica no Campus.

O tempo maior de fermentação no $2^{\circ}$ e $3^{\circ}$ ciclos provavelmente tenha sido resultante da inibição das por leveduras metabólitos alí presentes e que não existiam no $1^{\circ}$ ciclo, no mosto sadio, inclusive o etanol que é um inibidor; no mosto contaminado aliada a essa inibição estava presente também a inibição dos metabólitos do complexo

\subsection{Eficiência de Fermentação}

A Tabela 8 mostra o grau alcoólico do fermento reciclado dos ensaios, para o cálculo da eficiência e produtividade da fermentação. 
Tabela 8 - Resultados do grau alcoólico do fermento reciclado dos ensaios para cálculo da produtividade e eficiência fermentativa.

\begin{tabular}{|c|c|c|c|c|}
\hline \multirow[b]{2}{*}{ Ensaio } & & \multicolumn{3}{|c|}{ Ciclos Fermentativos $-{ }^{\circ} \mathrm{GL}$} \\
\hline & & $1^{0}$ & $2^{\circ}$ & $3^{\circ}$ \\
\hline \multirow[t]{2}{*}{1} & $\mathrm{CS}$ & 0 & 3,46 & 4,10 \\
\hline & $\mathrm{CC}$ & 0 & 3,60 & 4,46 \\
\hline \multirow[t]{2}{*}{4} & $\mathrm{CS}$ & 0 & 3,10 & 4,25 \\
\hline & $\mathrm{CC}$ & 0 & 3,32 & 4,39 \\
\hline \multirow[t]{2}{*}{5} & $\mathrm{CS}$ & 0 & 3,67 & 4,10 \\
\hline & $\mathrm{CC}$ & 0 & 3,25 & 3,95 \\
\hline \multirow[t]{2}{*}{6} & $\mathrm{CS}$ & 0 & 3,46 & 3,95 \\
\hline & $\mathrm{CC}$ & 0 & 3,60 & 4,10 \\
\hline \multirow[t]{2}{*}{7} & CS & 0 & 4,10 & 4,39 \\
\hline & $\mathrm{CC}$ & 0 & 3,95 & 3,88 \\
\hline \multirow[t]{2}{*}{8} & $\mathrm{CS}$ & 0 & 3,18 & 4,17 \\
\hline & $\mathrm{CC}$ & 0 & 3,18 & 3,60 \\
\hline \multirow[t]{2}{*}{9} & $\mathrm{CS}$ & 0 & 3,74 & 4,39 \\
\hline & $\mathrm{CC}$ & 0 & 3,32 & 4,03 \\
\hline \multirow[t]{2}{*}{10} & $\mathrm{CS}$ & 0 & 3,60 & 4,03 \\
\hline & $\mathrm{CC}$ & 0 & 3,10 & 4,39 \\
\hline
\end{tabular}

A queda da eficiência fermentativa foi observada a partir do $5^{\circ}$ ensaio, onde $o$ I.V.D. era da ordem de $8,00 \%$, no $4^{\circ}$ ensaio, quando o I.V.D. foi de $5,00 \%$, observou-se uma menor eficiência também (Tabela 9). Com um índice de I.V.D. acima de 5,00\%, talvez o ataque dos microrganismos invasores juntamente com a atividade do complexo tenha sido muito mais intensa deteriorando mais os colmos obtendo-se um mosto de qualidade inferior em relação ao conteúdo de açúcar total e acidez volátil (Figuras 4 e 5). 
Durante essa deterioração, a formação de metabólitos como os ácidos orgânicos é inevitável e esses por sua vez talvez tenham agido como inibidores, diminuindo portanto as eficiências de fermentação.

Quando os I.V.D. variaram de 2,85 a 5,07\%, (ensaios 1. 2, 3 e 4, Tabela 5), a influência sobre as eficiências não foi tão significativa como para os outros índices, principalmente para o ensaio 1 onde o I.V.D. foi de $2,85 \%$ e a eficiência fermentativa não foi prejudicada. Isto pode ser explicado através do experimento de MAIORELLA et al. (1983), que mostra que concentrações mínimas de contaminantes que produzem ácidos, podem estimular o metabolismo celular melhorando a fermentação. Através das Figuras 7 , 8 e 9 e da Tabela 9, observando-se que para todos os ensaios, o primeiro ciclo apresentaram diferenças maiores de eficiência entre sadio e o contaminado. Neste caso pode-se dizer que os metabólitos presentes no mosto contaminado devido a ação dos microrganismos invasores da cana-de-açúcar que agiram simultâneamente com a broca poderiam ter prejudicado as fermentações já que o inóculo utilizado não continha metabólitos ou outros produtos inibidores, provinientes da fermentação, pois para $o 1^{\circ}$ ciclo o inóculo era preparado a partir do fermento biológico prensado.

As Tabelas de 10 a 17 mostram o comportamento dos ensaios 3 a 10, em relação ao $\mathrm{pH}$, teor alcoólico, acidez volátil e açúcares residuais para o mosto sadio e mosto contaminado, com os respectivos I.V.D. Os ensaios 2 e 3 não foram computados pois não tiveram completados os 3 ciclos fermentativos. Para todos os ensaios com exceção do $4^{\circ}$ onde a amostra inicial foi coletada após 3 horas de fermentação, a coleta da amostra inicial era feita logo após a adição do mosto ao fermento. 


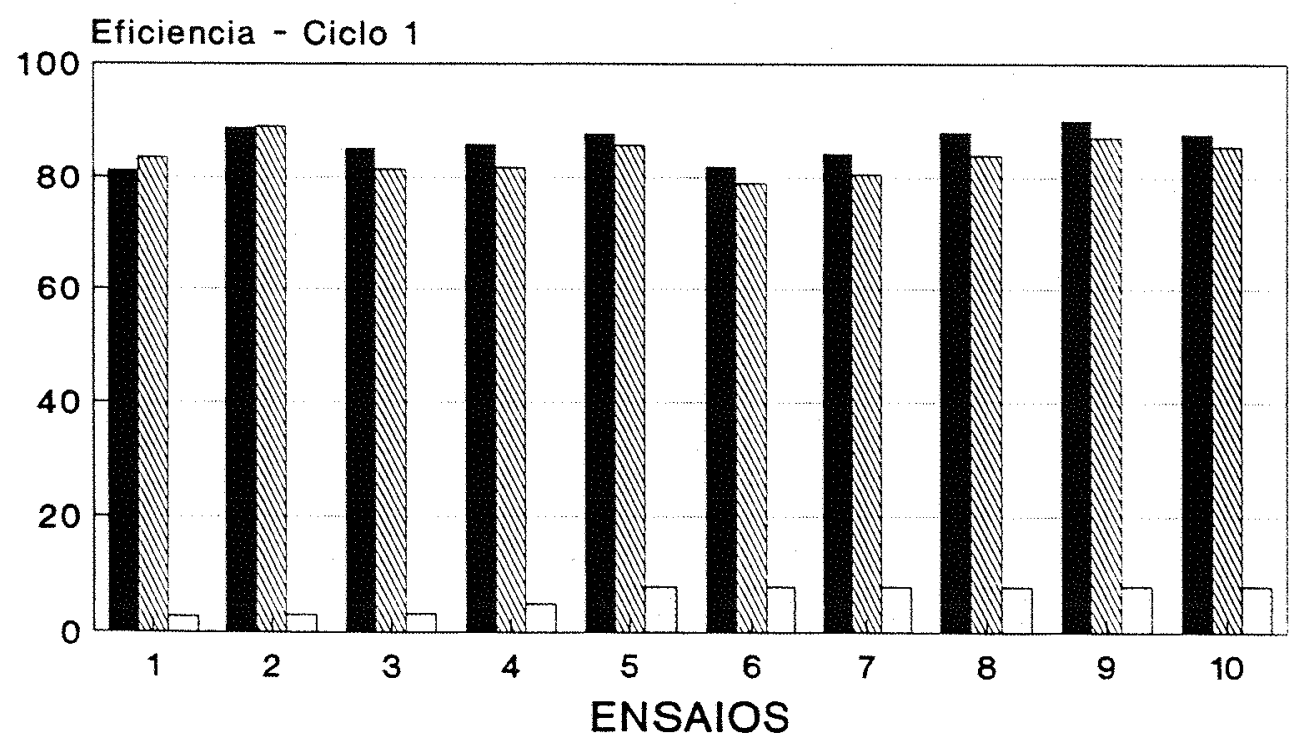

Ef. Caldo sadio $\quad$ Ef. Caldo contam. $\square$ IVD

Figura 7 - Resultados da eficiência da fermentação (\%). $1^{\circ}$ Ciclo. 


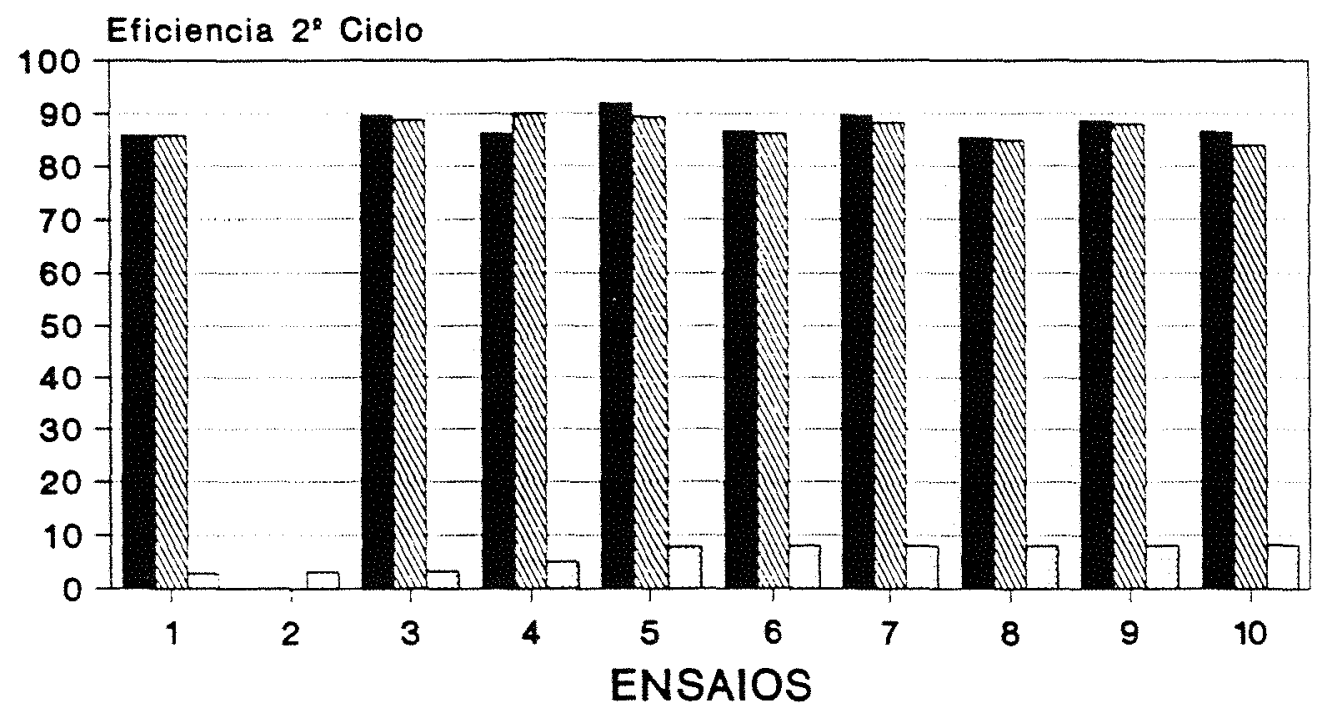

Ef.p/ caldo sadio $\$$ Ef.p/ caldo contam. $\square$ IVD

Figura 8 - Resultados de eficiência da fermentação (\%). $2^{\circ}$ Ciclo. 


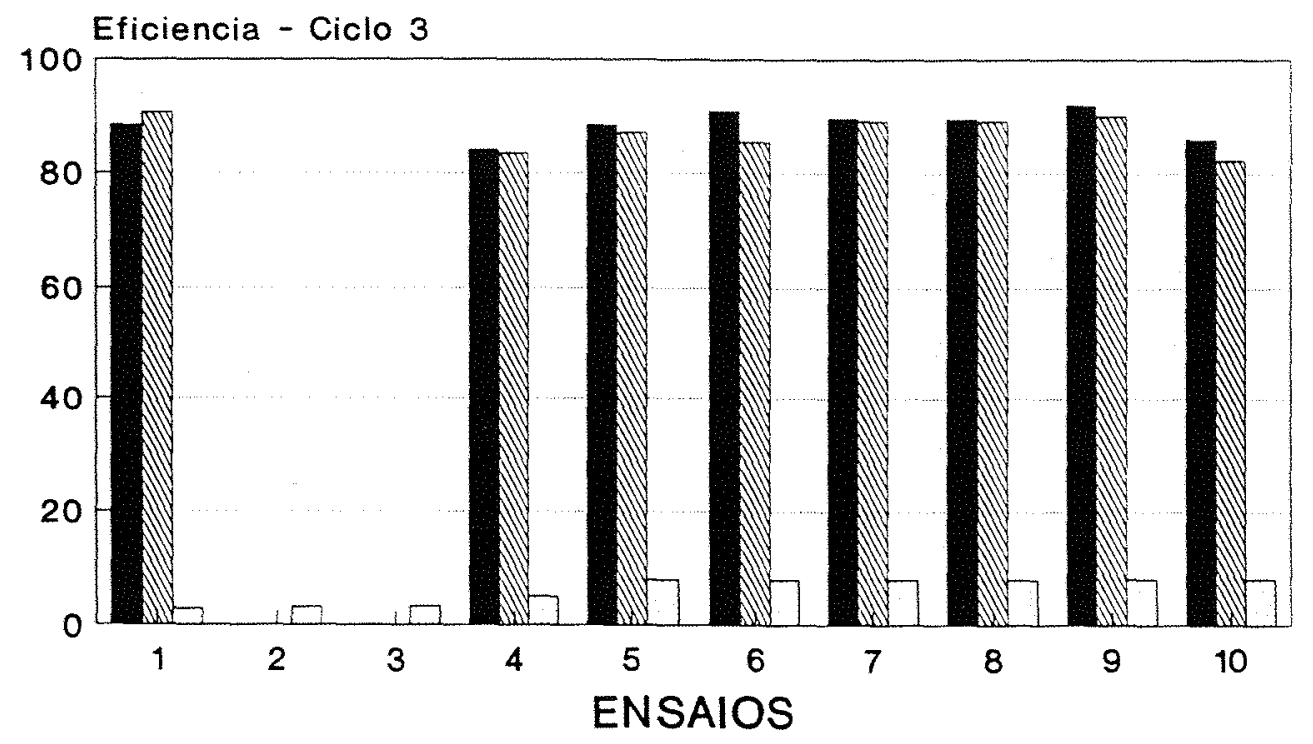

Ef. Caldo sadio MVith Ef. Caldo contam. $\square$ IVD

Figura 9 - Resultados de eficiência da fermentação (\%). $3^{\circ}$ Ciclo. 
Tabela 9 - Eficiência fermentativa.

\begin{tabular}{cccccccc}
\hline \hline & & \multicolumn{2}{c}{$1^{\circ}$ Ciclo } & \multicolumn{2}{c}{$2^{\circ}$ Ciclo } & \multicolumn{2}{c}{$3^{\circ}$ Ciclo } \\
\cline { 3 - 8 } Ensaio & IVD & CS & CC & CS & CC & CS & CC \\
\hline 1 & 2,85 & 81,15 & 83,45 & 85,78 & 85,88 & 88,30 & 90,55 \\
2 & 3,15 & 88,87 & 89,07 & - & - & - & - \\
3 & 3,26 & 85,15 & 81,44 & 89,53 & 88,72 & - & - \\
4 & 5,07 & 85,86 & 81,68 & 86,10 & 90,00 & 83,97 & 83,42 \\
5 & 7,92 & 87,77 & 85,65 & 91,95 & 89,28 & 88,34 & 87,09 \\
6 & 8,00 & 81,84 & 78,95 & 86,61 & 86,18 & 90,88 & 85,43 \\
7 & 8,03 & 84,19 & 80,63 & 89,57 & 88,17 & 89,49 & 89,11 \\
8 & 8,03 & 88,07 & 83,95 & 85,41 & 84,94 & 89,45 & 89,03 \\
9 & 8,10 & 90,17 & 87,21 & 88,57 & 87,83 & 91,83 & 90,00 \\
10 & 8,19 & 87,76 & 85,58 & 86,47 & 83,87 & 85,90 & 82,21 \\
\hline \hline
\end{tabular}

Tabela 10 - Comportamento da fermentação - ensaio 1.

IVD $=2,85$

\begin{tabular}{cccccccccc}
\hline \hline \multirow{2}{*}{$\begin{array}{c}\text { Ensaio } \\
1\end{array}$} & \multicolumn{4}{c}{ Amostra Inicial } & \multicolumn{4}{c}{ Amostra Final } \\
\cline { 2 - 9 } & Mosto & $\mathrm{pH}$ & ${ }^{\circ} \mathrm{GL}$ & Ac.Volát. & $\mathrm{pH}$ & ${ }^{\circ} \mathrm{GL}$ & $\begin{array}{c}\text { Ác. Volát. } \\
\text { mg/100ml }\end{array}$ & $\begin{array}{c}\text { Aç. Res. } \\
\mathrm{g} / 1\end{array}$ \\
\hline $1^{\circ} \mathrm{C}$ & $\mathrm{S}$ & 4,29 & 0,70 & 10,48 & 3,46 & 7,04 & 10,48 & 0,305 \\
& $\mathrm{C}$ & 3,89 & 0,70 & 10,71 & 3,00 & 7,19 & 10,71 & 0,294 \\
\hline $2^{\circ} \mathrm{C}$ & $\mathrm{S}$ & 4,05 & 1,72 & 10,74 & 3,60 & 8,48 & 12,17 & 0,419 \\
& $\mathrm{C}$ & 3,27 & 1,99 & 12,34 & 3,28 & 8,48 & 12,34 & 0,410 \\
\hline $3^{\circ} \mathrm{C}$ & $\mathrm{S}$ & 3,86 & 2,33 & 6,05 & 3,44 & 8,89 & 12,57 & 0,286 \\
& $\mathrm{C}$ & 3,22 & 2,33 & 10,71 & 3,08 & 9,14 & 12,57 & 0,548 \\
\hline \hline
\end{tabular}


Tabela 11 - Comportamento da fermentação - ensaio 4.

\begin{tabular}{ccccccccc} 
IVD $=5,07$ & \multicolumn{7}{c}{ Amostra Final } \\
\hline \hline Ensaio & \multicolumn{9}{c}{ Amostra Inicial } \\
\cline { 2 - 9 } 1 & Mosto & $\mathrm{pH}$ & ${ }^{\circ} \mathrm{GL}$ & Ac.Volát. & $\mathrm{pH}$ & ${ }^{\circ} \mathrm{GL}$ & $\begin{array}{c}\text { Ác. Volát. } \\
\mathrm{mg} / 100 \mathrm{ml}\end{array}$ & $\begin{array}{c}\text { Aç.Res. } \\
\mathrm{g} / \mathrm{l}\end{array}$ \\
\hline $1^{\circ} \mathrm{C}$ & $\mathrm{S}$ & 3,15 & 4,10 & 13,97 & 3,20 & 7,04 & 13,97 & 0,305 \\
& $\mathrm{C}$ & 3,26 & 4,17 & 16,76 & 3,32 & 6,72 & 14,43 & 0,527 \\
\hline $2^{\circ} \mathrm{C}$ & $\mathrm{S}$ & 3,23 & 3,46 & 16,30 & 3,19 & 7,99 & 11,17 & 0,442 \\
& $\mathrm{C}$ & 3,28 & 4,03 & 16,76 & 3,38 & 8,40 & 12,80 & 0,548 \\
\hline $3^{\circ} \mathrm{C}$ & $\mathrm{S}$ & 3,21 & 3,03 & 9,77 & 3,12 & 8,16 & 11,17 & 0,304 \\
& $\mathrm{C}$ & 3,18 & 3,46 & 9,78 & 3,21 & 8,18 & 12,34 & 0,417 \\
\hline \hline
\end{tabular}

Tabela 12 - Comportamento da fermentação - ensaio 5.

$\operatorname{IVD}=7,92$

\begin{tabular}{ccccccccc}
\hline \hline \multirow{2}{*}{\begin{tabular}{c} 
Ensaio \\
\cline { 2 - 9 } 1
\end{tabular}} & \multicolumn{4}{c}{ Amostra Inicial } & \multicolumn{5}{c}{ Amostra Final } \\
\cline { 2 - 9 } & Mosto & $\mathrm{pH}$ & ${ }^{\circ} \mathrm{GL}$ & Ac. Volát. & $\mathrm{pH}$ & ${ }^{\circ} \mathrm{GL}$ & $\begin{array}{c}\text { Ác. Volát. } \\
\mathrm{mg} / 100 \mathrm{ml}\end{array}$ & $\begin{array}{c}\text { Aç. Res. } \\
\mathrm{g} / 1\end{array}$ \\
\hline $1^{\circ} \mathrm{C}$ & $\mathrm{S}$ & 3,40 & 0,48 & 7,73 & 2,80 & 7,75 & 8,49 & 0,352 \\
& $\mathrm{C}$ & 3,46 & 0,56 & 10,52 & 3,00 & 7,43 & 9,96 & 0,478 \\
\hline $2^{\circ} \mathrm{C}$ & $\mathrm{S}$ & 3,29 & 1,72 & 7,91 & 3,18 & 9,22 & 9,87 & 0,464 \\
& $\mathrm{C}$ & 3,24 & 1,44 & 5,73 & 3,34 & 8,72 & 12,57 & 0,441 \\
\hline $3^{\circ} \mathrm{C}$ & $\mathrm{S}$ & 3,95 & 3,18 & 6,98 & 3,01 & 9,03 & 8,24 & 0,703 \\
& $\mathrm{C}$ & 3,95 & 3,25 & 6,52 & 3,25 & 8,74 & 10,80 & 0,584 \\
\hline \hline
\end{tabular}


Tabela 13 - Comportamento da fermentação - ensaio 6.

$\operatorname{IVD}=8,00$

\begin{tabular}{ccccccccc}
\hline \hline Ensaio & \multicolumn{4}{c}{ Amostra Inicial } & \multicolumn{5}{c}{ Amostra Final } \\
\cline { 2 - 9 } 1 & Mosto & $\mathrm{pH}$ & ${ }^{\circ} \mathrm{GL}$ & Ac.Volát. & $\mathrm{pH}$ & ${ }^{\circ} \mathrm{GL}$ & $\begin{array}{c}\text { Ác.Volát. } \\
\mathrm{mg} / 100 \mathrm{ml}\end{array}$ & $\begin{array}{c}\text { Aç.Res. } \\
\mathrm{g} / 1\end{array}$ \\
\hline $1^{\circ} \mathrm{C}$ & $\mathrm{S}$ & 3,83 & 0,70 & 9,73 & 3,00 & 6,57 & 10,07 & 0,351 \\
& $\mathrm{C}$ & 3,96 & 0,63 & 14,34 & 3,10 & 6,33 & 9,31 & 0,465 \\
\hline $2^{\circ} \mathrm{C}$ & $\mathrm{S}$ & 3,56 & 1,51 & 6,98 & 3,33 & 7,99 & 13,41 & 0,398 \\
& $\mathrm{C}$ & 3,58 & 1,37 & 5,40 & 3,35 & 7,99 & 14,43 & 0,597 \\
\hline $3^{\circ} \mathrm{C}$ & $\mathrm{S}$ & 3,48 & 1,99 & 15,08 & 3,44 & 8,48 & 16,24 & 0,401 \\
& $\mathrm{C}$ & 3,42 & 1,72 & 15,27 & 3,40 & 8,08 & 16,68 & 0,598 \\
\hline \hline
\end{tabular}

Tabela 14 - Comportamento da fermentação - ensaio 7.

IVD $=8,03$

\begin{tabular}{ccccccccc}
\hline \hline Ensaio & \multicolumn{4}{c}{ Amostra Inicial } & \multicolumn{5}{c}{ Amostra Final } \\
\cline { 2 - 9 } 1 & Mosto & $\mathrm{pH}$ & ${ }^{\circ} \mathrm{GL}$ & Ac.Volát. & $\mathrm{pH}$ & ${ }^{\circ} \mathrm{GL}$ & $\begin{array}{c}\text { Ác.Volát. } \\
\mathrm{mg} / 100 \mathrm{ml}\end{array}$ & $\begin{array}{c}\text { Aç.Res. } \\
\mathrm{g} / 1\end{array}$ \\
\hline $1^{\circ} \mathrm{C}$ & $\mathrm{S}$ & 3,70 & 0,63 & 14,81 & 3,04 & 7,51 & 14,67 & 0,455 \\
& $\mathrm{C}$ & 3,49 & 0,63 & 13,83 & 2,94 & 6,90 & 17,32 & 0,446 \\
\hline $2^{\circ} \mathrm{C}$ & $\mathrm{S}$ & 3,40 & 1,72 & 13,50 & 3,41 & 9,22 & 14,99 & 0,474 \\
& $\mathrm{C}$ & 3,30 & 1,79 & 10,15 & 3,35 & 8,73 & 14,99 & 0,521 \\
\hline $3^{\circ} \mathrm{C}$ & $\mathrm{S}$ & 3,32 & 2,40 & 14,62 & 3,15 & 9,30 & 11,17 & 1,161 \\
& $\mathrm{C}$ & 3,27 & 2,33 & 14,71 & 3,00 & 8,79 & 12,52 & 0,863 \\
\hline \hline
\end{tabular}


Tabela 15 - Comportamento da fermentação - ensaio 8.

$\operatorname{IVD}=8,03$

\begin{tabular}{ccccccccc}
\hline \hline \multirow{2}{*}{\begin{tabular}{c} 
Ensaio \\
\cline { 2 - 9 }
\end{tabular}} & \multicolumn{4}{c}{ Amostra Inicial } & \multicolumn{5}{c}{ Amostra Final } \\
\cline { 2 - 9 } & Mosto & $\mathrm{pH}$ & ${ }^{\circ} \mathrm{GL}$ & Ac.Volát. & $\mathrm{pH}$ & ${ }^{\circ} \mathrm{GL}$ & $\begin{array}{c}\text { Ác.Volát. } \\
\mathrm{mg} / 100 \mathrm{ml}\end{array}$ & $\begin{array}{c}\text { Aç.Res. } \\
\mathrm{g} / \mathrm{l}\end{array}$ \\
\hline $1^{\circ} \mathrm{C}$ & $\mathrm{S}$ & 3,92 & 0,56 & 8,75 & 3,35 & 7,51 & 15,27 & 0,441 \\
& $\mathrm{C}$ & 3,90 & 0,63 & 8,47 & 3,44 & 7,04 & 13,22 & 0,459 \\
\hline $2^{\circ} \mathrm{C}$ & $\mathrm{S}$ & 3,67 & 1,30 & 15,60 & 3,32 & 8,24 & 20,30 & 0,608 \\
& $\mathrm{C}$ & 3,70 & 1,37 & 14,67 & 3,30 & 8,08 & 17,13 & 0,594 \\
\hline $3^{\circ} \mathrm{C}$ & $\mathrm{S}$ & 3,59 & 1,72 & 11,08 & 3,51 & 8,88 & 20,39 & 1,322 \\
& $\mathrm{C}$ & 3,55 & 1,79 & 13,04 & 3,57 & 8,55 & 18,25 & 0,708 \\
\hline \hline
\end{tabular}

Tabela 16 - Comportamento da fermentação - ensaio 9.

IVD $=8,10$

\begin{tabular}{ccccccccc}
\hline \hline Ensaio & \multicolumn{4}{c}{ Amostra Inicial } & \multicolumn{4}{c}{ Amostra Final } \\
\cline { 2 - 8 } 1 & Mosto & $\mathrm{pH}$ & ${ }^{\circ} \mathrm{GL}$ & Ac.Volát. & $\mathrm{pH}$ & ${ }^{\circ} \mathrm{GL}$ & $\begin{array}{c}\text { Ác.Volát. } \\
\mathrm{mg} / 100 \mathrm{ml}\end{array}$ & $\begin{array}{c}\text { Aç. Res. } \\
\mathrm{g} / 1\end{array}$ \\
\hline $1^{\circ} \mathrm{C}$ & $\mathrm{S}$ & 3,51 & 0,36 & 13,04 & 3,04 & 7,99 & 15,36 & 0,417 \\
& $\mathrm{C}$ & 3,43 & 0,44 & 13,97 & 3,04 & 7,51 & 15,41 & 0,488 \\
\hline $2^{\circ} \mathrm{C}$ & $\mathrm{S}$ & 3,46 & 1,85 & 10,24 & 3,29 & 8,97 & 14,53 & 0,580 \\
& $\mathrm{C}$ & 3,46 & 1,72 & 10,01 & 3,15 & 8,56 & 10,24 & 0,584 \\
\hline $3^{\circ} \mathrm{C}$ & $\mathrm{S}$ & 3,34 & 1,99 & 12,94 & 3,07 & 9,45 & 13,04 & 1,773 \\
& $\mathrm{C}$ & 3,35 & 1,72 & 12,85 & 2,97 & 8,97 & 13,32 & 0,733 \\
\hline \hline
\end{tabular}


Tabela 17 - Comportamento da fermentação - ensaio 10.

$\operatorname{IVD}=8,19$

\begin{tabular}{ccccccccc}
\hline \hline Ensaio & \multicolumn{4}{c}{ Amostra Inicial } & \multicolumn{4}{c}{ Amostra Final } \\
\cline { 2 - 9 } 1 & Mosto & $\mathrm{pH}$ & ${ }^{\circ} \mathrm{GL}$ & Ac.Volát. & $\mathrm{pH}$ & ${ }^{\circ} \mathrm{GL}$ & $\begin{array}{c}\text { Ác.Volát. } \\
\mathrm{mg} / 100 \mathrm{ml}\end{array}$ & $\begin{array}{c}\text { Aç.Res. } \\
\mathrm{g} / \mathrm{l}\end{array}$ \\
\hline $1^{\circ} \mathrm{C}$ & $\mathrm{S}$ & 3,91 & 0,56 & 12,06 & 3,18 & 7,51 & 16,43 & 0,536 \\
& $\mathrm{C}$ & 3,70 & 0,56 & 12,29 & 3,10 & 7,04 & 16,43 & 0,517 \\
\hline $2^{\circ} \mathrm{C}$ & $\mathrm{S}$ & 3,59 & 1,65 & 15,27 & 3,54 & 8,48 & 17,23 & 0,639 \\
& $\mathrm{C}$ & 3,45 & 1,58 & 15,36 & 3,40 & 7,83 & 16,76 & 0,639 \\
\hline $3^{\circ} \mathrm{C}$ & $\mathrm{S}$ & 3,38 & 1,79 & 15,27 & 3,17 & 8,56 & 17,32 & 0,538 \\
& $\mathrm{C}$ & 3,29 & 1,72 & 15,27 & 3,10 & 8,08 & 17,23 & 0,549 \\
\hline \hline
\end{tabular}

\subsection{Produtividade da fermentação - $\rho$}

Quando o I.V.D. foi da ordem de 8,00\%, a tendência foi que o fermentador com o mosto contaminado tivesse em todos os ciclos de fermentação uma eficiência menor em relação ao fermentador com o mosto sadio, conforme equação do ítem 3.5. Isto reforça o efeito inibidor de certas substâncias formadas quando a broca e os microrganismos agiram simultaneamente. Foi observado que para todos os ensaios, o primeiro ciclo teve uma produtividade melhor que os dois seguintes, tanto para o mosto sadio como para o mosto "contaminado". Nesse caso, inibidores como o etanol e os ácidos não estavam presentes no início da fermentação, resultando numa melhor produividade em relação aos ciclos seguintes; porém a produtividade do mosto contaminado foi sempre menor. A Tabela 18 e os gráficos 10,11 e 12, mostram resultados das produtividades de fermentação. 
Tabela 18 - Produtividade de fermentação (G etanol/1/h).

\begin{tabular}{cccccccc}
\hline \hline & & \multicolumn{2}{c}{$1^{\circ}$ Ciclo } & \multicolumn{2}{c}{$2^{\circ}$ Ciclo } & \multicolumn{2}{c}{$3^{\circ}$ Ciclo } \\
\cline { 3 - 8 } Ensaio & IVD & CS & CC & CS & CC & CS & CC \\
\hline 1 & 2,85 & 11,18 & 11,42 & 6,91 & 6,87 & 8,33 & 8,49 \\
4 & 5,07 & 10,86 & 10,36 & 5,61 & 6,16 & 5,94 & 5,92 \\
5 & 7,92 & 11,73 & 11,24 & 7,96 & 7,59 & 7,65 & 7,41 \\
6 & 8,00 & 12,43 & 11,97 & 6,61 & 6,57 & 7,11 & 6,68 \\
7 & 8,03 & 9,96 & 8,81 & 7,74 & 7,31 & 6,97 & 6,69 \\
8 & 8,03 & 8,40 & 7,88 & 7,72 & 7,54 & 8,42 & 8.24 \\
9 & 8,10 & 10,15 & 9,70 & 6,93 & 6,67 & 7,88 & 7,49 \\
10 & 8,19 & 9,70 & 9,09 & 7,12 & 6,64 & 7,16 & 6,59 \\
\hline \hline
\end{tabular}

Obs: Os $2^{\circ}$ e $3^{\circ}$ ensaios não tiveram seus ciclos completados devido a falta de energia elétrica no Campus.

\section{6. pH durante as fermentações}

De maneira geral, as medidas de $\mathrm{pH}$ para todos os ensaios (Tabelas 10 a 17) foram menores no final das fermentações, en todos os ciclos. A medida de $\mathrm{pH}$ não foi um bom parâmetro para avaliação do complexo sobre a fermentação, pois durante a fermentação muitos produtos são formados como ácidos voláteis que interferem na medida do $\mathrm{pH}$ mascarando o efeito do complexo. 


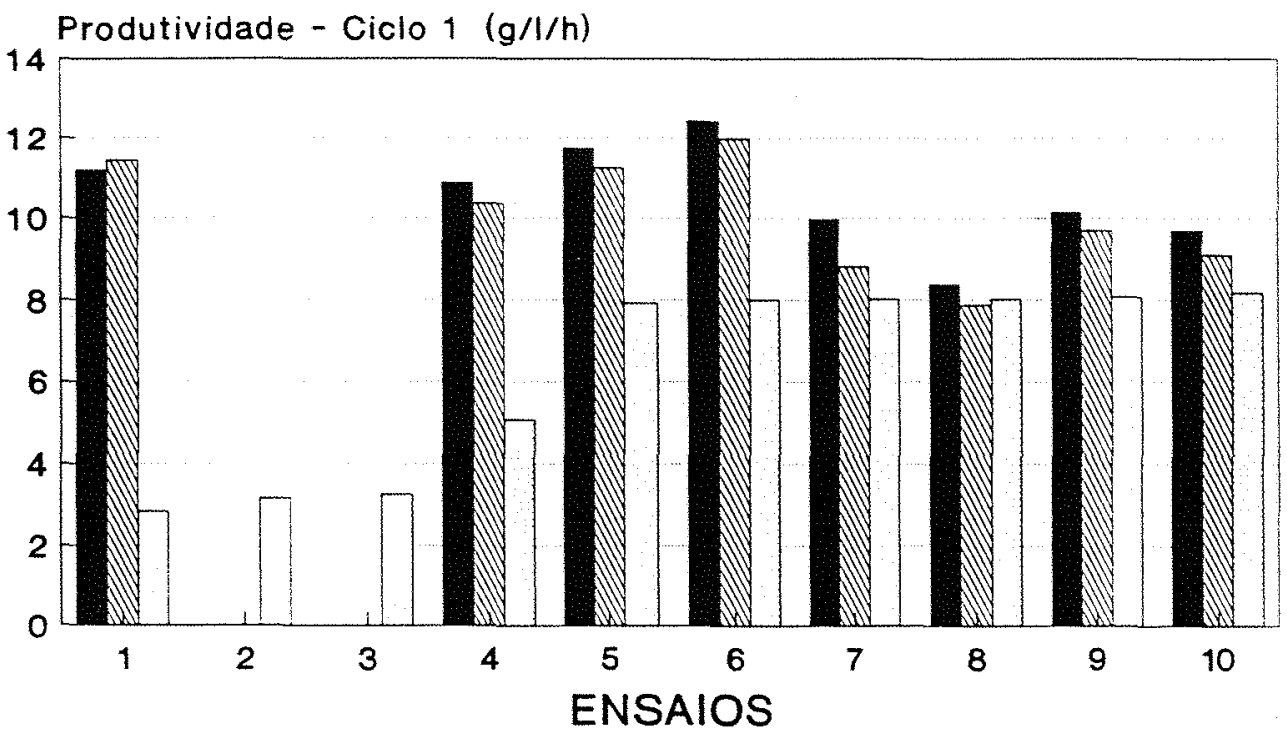

W Prod. Caldo sadio $\$$ Prod. Caldo contam. $\square$ IVD

Figura 10 - Resultados da produtividade da fermentação (g etanol/l.h) $-1^{\circ}$ Ciclo 


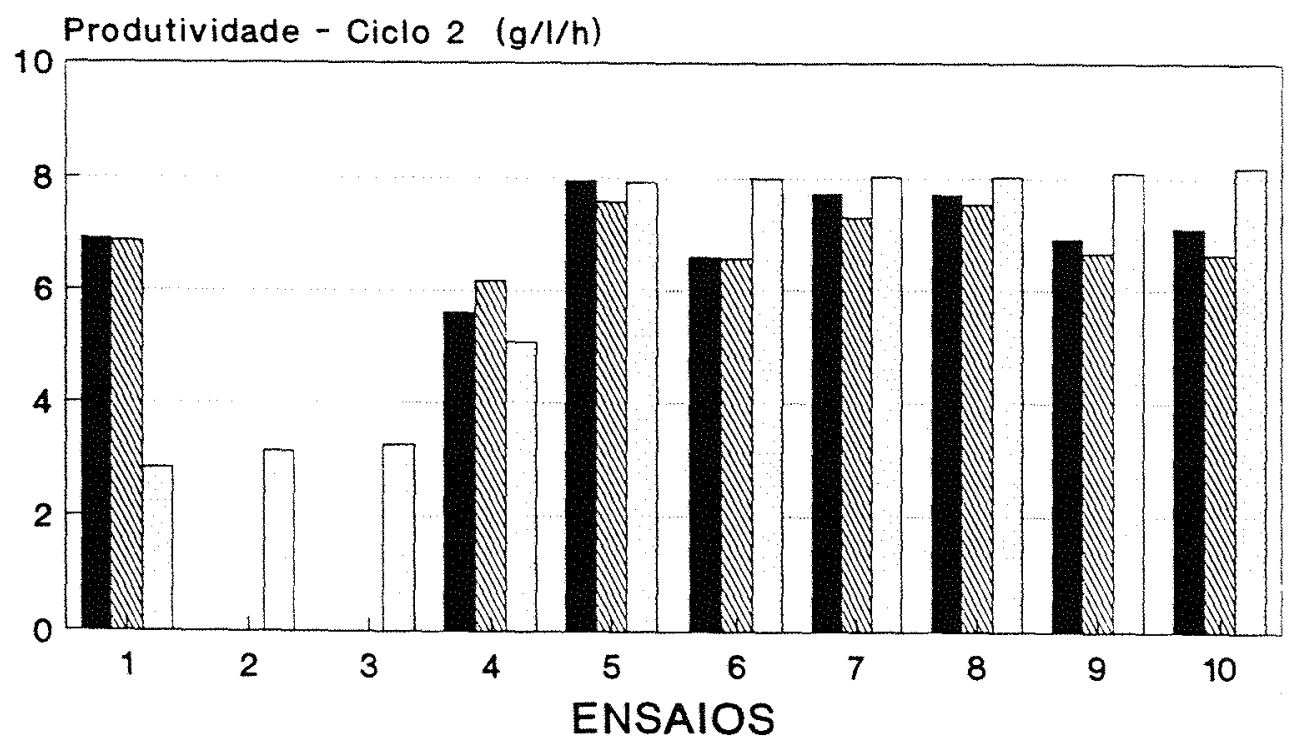

Drod. Caldo sadio $\mathbb{M U H}$ Prod. Caldo contam. $\quad \square$ IVD

Figura 11 - Resultados da produtividade da fermentação (g etanol/1.h). $2^{\circ}$ Ciclo. 


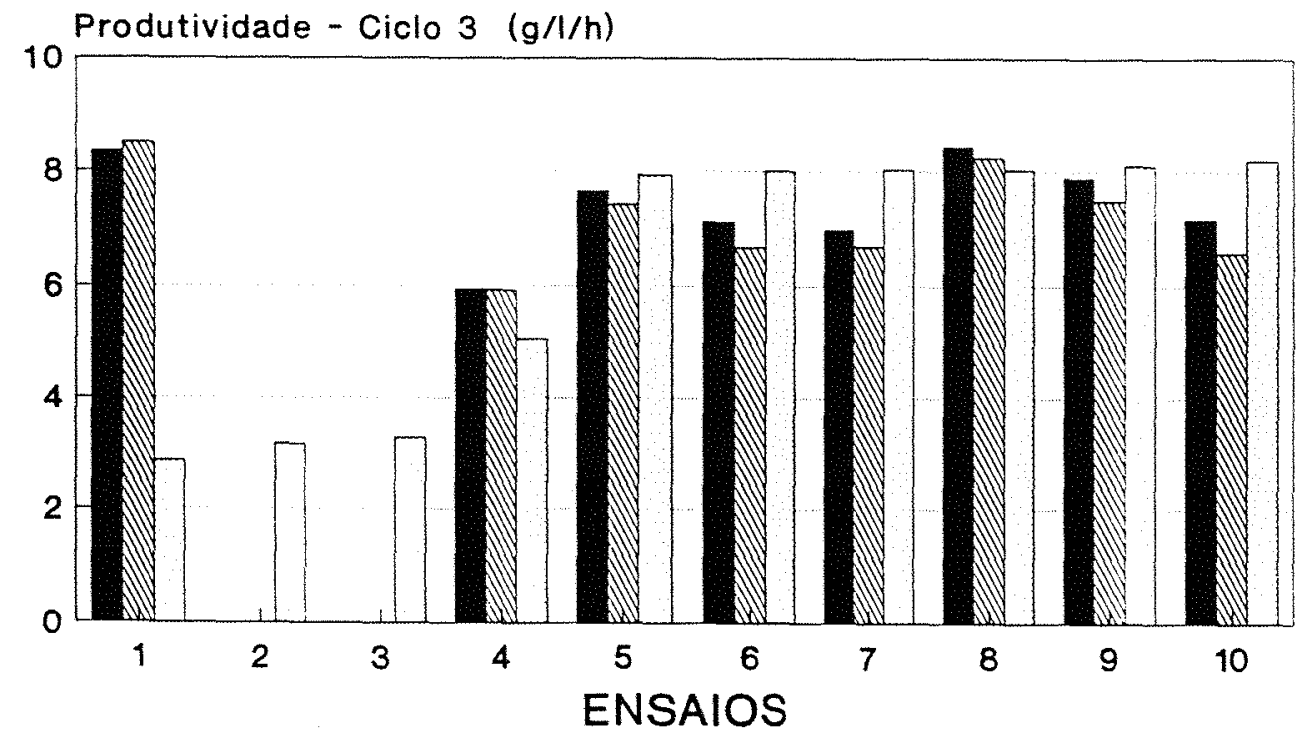

Prod. Caldo sadio $\quad$ Mille Prod. Caldo contam. $\quad$ IVD

Figura 12 - Resultados da produtividade da fermentação (g etanol/1.h). $3^{\circ}$ Ciclo. 


\subsection{Acidez volátil na fermentação}

Analisou-se a acidez volátil durante os ensaios, por ela ser considerada um bom índice para avaliar a contaminação de uma fermentação, já que os microrganismos contaminantes têm como produto de seus metabolismos ácidos orgânicos como acético, málico, láctico, que são voláteis. A Tabela 19 mostra os resultados obtidos durante o experimento.

A acidez volátil determinada por titulação potenciométrica não mostrou resultados satisfatórios para os ensaios. Porém de um modo geral, como era esperado, a acidez volátil final para todos os ciclos apresentou-se maior para o mosto contaminado.

\subsection{Metabolismo celular}

As Tabelas de 20 a 27, mostram o comportamento das leveduras durante as fermentações e seus reciclos nas diferentes situações de mosto; o mosto sadio (dorna testemunha) e o mosto contaminado (Broca/podridão). De um modo geral houve sempre uma tendência de se ter uma quantidade menor de celulas por mililitro no fermentador com o mosto contaminado o que pode indicar um efeito inibitório do complexo em relação a reprodução celular; sendo que a viabilidade e brotamento celular não foram comprometidos, pois ora se apresentavam menores, ora maiores em relação ao fermentador com o mosto sadio.

Durante todo o experimento o número de células/ $\mathrm{ml}$ nas dornas variou de 5,9 $\times 10^{8}$ a $2,4 \times 10^{9} \mathrm{cels} / \mathrm{ml}$, enquanto que a viabilidade e o brotamento celular variaram de 70,94 à $98,94 \%$ e 0,43 à 16,11 respectivamente. O metabolismo celular em relação à viabilidade, brotamento e células por mililitro não foi alterado para nenhuma das situações de I.V.D. estudadas. 
Tabela 19 - Resultados da acidez volátil (mg/ $100 \mathrm{ml}$ ) em todos os ensaios.

\begin{tabular}{|c|c|c|c|c|c|c|c|}
\hline \multirow{2}{*}{\multicolumn{2}{|c|}{$\begin{array}{l}\text { Ensaios } \\
\qquad \text { Ferm. }\end{array}$}} & \multicolumn{2}{|c|}{$1^{o}$} & \multicolumn{2}{|c|}{$2^{\circ}$} & \multicolumn{2}{|c|}{$3^{\circ}$} \\
\hline & & CS & $\mathrm{CC}$ & $\mathrm{CS}$ & $\mathrm{CC}$ & CS & $\mathrm{CC}$ \\
\hline \multirow[t]{2}{*}{1} & I & 10,48 & 10,71 & 12,34 & 10,71 & 6,05 & 10,71 \\
\hline & $F$ & 10,48 & 10,71 & 12,34 & 11,17 & 12,57 & 12,57 \\
\hline \multirow[t]{2}{*}{2} & I & - & - & - & - & - & - \\
\hline & $\mathrm{F}$ & - & - & - & - & - & - \\
\hline \multirow[t]{2}{*}{3} & I & 16,60 & 18,42 & 19,73 & 15,70 & - & - \\
\hline & $\mathrm{F}$ & 14,64 & 16,60 & 18,62 & 19,76 & - & - \\
\hline \multirow[t]{2}{*}{4} & I & 13,97 & 16,76 & 16,30 & 16,76 & 9,78 & 9,78 \\
\hline & $\mathrm{F}$ & 13,97 & 14,43 & 11,17 & 12,80 & 11,17 & 12,34 \\
\hline \multirow[t]{2}{*}{5} & I & 7,73 & 8,52 & 7,91 & 5,73 & 6,98 & 6,52 \\
\hline & $\mathrm{F}$ & 8,94 & 10,96 & 9,87 & 12,57 & 8,24 & 10,80 \\
\hline \multirow[t]{2}{*}{6} & I & 9,73 & 14,34 & 6,98 & 5,40 & 15,58 & 15,27 \\
\hline & $\mathrm{F}$ & 10,07 & 9,31 & 13,41 & 14,43 & 16,24 & 16,68 \\
\hline \multirow[t]{2}{*}{7} & I & 14,81 & 15,83 & 10,50 & 13,15 & 14,62 & 14,71 \\
\hline & $\mathrm{F}$ & 14,67 & 17,32 & 14,99 & 14,99 & 15,17 & 12,52 \\
\hline \multirow[t]{2}{*}{8} & I & 8,75 & 8,47 & 15,60 & 14,67 & 11,08 & 13,04 \\
\hline & $\mathrm{F}$ & 13,27 & 15,22 & 20,30 & 17,13 & 18,39 & 20,25 \\
\hline \multirow[t]{2}{*}{9} & I & 13,04 & 13,97 & 10,24 & 10,01 & 12,94 & 12,85 \\
\hline & F & 15,36 & 15,41 & 14,53 & 10,24 & 13,04 & 13,32 \\
\hline \multirow[t]{2}{*}{10} & I & 12,06 & 12,29 & 15,27 & 13,36 & 15,27 & 15,27 \\
\hline & & 16,43 & 16,43 & 16,23 & 17,76 & 17,23 & 17,32 \\
\hline
\end{tabular}


Tabela 20 - Comportamento celular durante a fermentação. Ensaio 1.

\begin{tabular}{|c|c|c|c|c|}
\hline \multicolumn{2}{|c|}{$\begin{array}{c}\text { Ensaio } 1 \\
\text { IVD } 2,85 \\
\end{array}$} & \multirow{2}{*}{$\begin{array}{l}\begin{array}{c}\text { Células de } \\
\text { levedura/ml }\end{array} \\
8,29 \times 10^{8}\end{array}$} & \multirow{2}{*}{$\begin{array}{c}\begin{array}{c}\text { Viabilidade } \\
(\%)\end{array} \\
98,47\end{array}$} & \multirow{2}{*}{$\begin{array}{c}\begin{array}{c}\text { Brotamento } \\
(\%)\end{array} \\
0,61\end{array}$} \\
\hline $1^{o}$ & $\mathrm{CS}$ & & & \\
\hline & $\mathrm{CC}$ & $9,98 \times 10^{8}$ & 96,96 & 1,52 \\
\hline & $\mathrm{CS}$ & $7,73 \times 10^{8}$ & 97,38 & 1,96 \\
\hline & $\mathrm{CC}$ & $9.28 \times 10^{8}$ & 97,55 & 1,63 \\
\hline \multirow[t]{4}{*}{$2^{\circ}$} & $\mathrm{CS}$ & $1,69 \times 10^{9}$ & 97,88 & 1,35 \\
\hline & $\mathrm{CC}$ & $1,72 \times 10^{9}$ & 97,16 & 1,70 \\
\hline & $\mathrm{CS}$ & $1,40 \times 10^{9}$ & 95,87 & 0,65 \\
\hline & $\mathrm{CC}$ & $1,00 \times 10^{9}$ & 96,11 & 0,43 \\
\hline \multirow[t]{4}{*}{$3^{\circ}$} & $\mathrm{CS}$ & $1,30 \times 10^{9}$ & 95,18 & 1,15 \\
\hline & $\mathrm{CC}$ & $1,30 \times 10^{9}$ & 95,82 & 0,70 \\
\hline & $\mathrm{CS}$ & $9,90 \times 10^{8}$ & 87,79 & 1,27 \\
\hline & $\mathrm{CC}$ & $10,0 \times 10^{8}$ & 89,38 & 0,84 \\
\hline
\end{tabular}

Tabela 21 - Comportamento celular durante a fermentação. Ensaio 4.

\begin{tabular}{|c|c|c|c|c|}
\hline \multicolumn{2}{|c|}{$\begin{array}{c}\text { Ensaio } 1 \\
\text { IVD } 5.07 \\
\end{array}$} & \multirow{2}{*}{$\begin{array}{l}\begin{array}{c}\text { Células de } \\
\text { levedura/ml }\end{array} \\
2,4 \times 10^{9}\end{array}$} & \multirow{2}{*}{$\begin{array}{c}\begin{array}{c}\text { Viabilidade } \\
(\%)\end{array} \\
98,28\end{array}$} & \multirow{2}{*}{$\begin{array}{c}\text { Brotamento } \\
(\%) \\
1,41\end{array}$} \\
\hline $1^{\circ}$ & $\mathrm{CS}$ & & & \\
\hline & $\mathrm{CC}$ & $2,3 \times 10^{9}$ & 96,06 & 2,12 \\
\hline & $\mathrm{CS}$ & $1,4 \times 10^{9}$ & 97,94 & 1,83 \\
\hline & $\mathrm{CC}$ & $1,3 \times 10^{9}$ & 96,75 & 3,25 \\
\hline \multirow[t]{4}{*}{$2^{\circ}$} & $\mathrm{CS}$ & $1,8 \times 10^{9}$ & 98,20 & 1,00 \\
\hline & $\mathrm{CC}$ & $1,8 \times 10^{9}$ & 97,70 & 1,20 \\
\hline & $\mathrm{CS}$ & $1,4 \times 10^{9}$ & 98,50 & 2,50 \\
\hline & $\mathrm{CC}$ & $1,3 \times 10^{9}$ & 96,70 & 1,60 \\
\hline \multirow[t]{4}{*}{$3^{\circ}$} & $\mathrm{CS}$ & $9,3 \times 10^{8}$ & 95,43 & 2,31 \\
\hline & $\mathrm{CC}$ & $9,0 \times 10^{8}$ & 95,29 & 2,91 \\
\hline & $\mathrm{CS}$ & $1,0 \times 10^{9}$ & 97,47 & 2,52 \\
\hline & $\mathrm{CC}$ & $8,0 \times 10^{8}$ & 99,16 & 1,58 \\
\hline
\end{tabular}


Tabela 22 - Comportamento celular da fermentação. Ensaio 5.

\begin{tabular}{|c|c|c|c|c|}
\hline \multicolumn{2}{|c|}{$\begin{array}{c}\text { Ensaio } 1 \\
\text { IVD } 7.92 \\
\end{array}$} & \multirow{2}{*}{$\begin{array}{l}\text { Células de } \\
\text { levedura/ml } \\
1,0 \times 10^{9}\end{array}$} & \multirow{2}{*}{$\begin{array}{c}\text { Viabilidade } \\
(\%) \\
98,80\end{array}$} & \multirow{2}{*}{$\begin{array}{c}\text { Brotamento } \\
(\%) \\
1,73\end{array}$} \\
\hline $1^{0}$ & $\mathrm{CS}$ & & & \\
\hline & $\mathrm{CC}$ & $1,5 \times 10^{9}$ & 99,20 & 2,67 \\
\hline & $\mathrm{CS}$ & $1,0 \times 10^{9}$ & 96,60 & 3,13 \\
\hline & $\mathrm{CC}$ & $1,2 \times 10^{9}$ & 94,90 & 3,82 \\
\hline \multirow[t]{4}{*}{$2^{\circ}$} & CS & $1,1 \times 10^{9}$ & 92,70 & 1,33 \\
\hline & $\mathrm{CC}$ & $9,1 \times 10^{8}$ & 92,20 & 1,11 \\
\hline & CS & $1,2 \times 10^{9}$ & 88,50 & 1,64 \\
\hline & $\mathrm{CC}$ & $1,1 \times 10^{9}$ & 90,10 & 1,10 \\
\hline \multirow[t]{4}{*}{$3^{\circ}$} & CS & $1,0 \times 10^{9}$ & 89,40 & 1,48 \\
\hline & $\mathrm{CC}$ & $9,6 \times 10^{8}$ & 88,90 & 1,05 \\
\hline & CS & $5,9 \times 10^{8}$ & 82,69 & 2,31 \\
\hline & $\mathrm{CC}$ & $1,1 \times 10^{9}$ & 77,65 & 2,26 \\
\hline
\end{tabular}

Tabela 23 - Comportamento celular da fermentação. Ensaio 6.

\begin{tabular}{|c|c|c|c|c|}
\hline \multicolumn{2}{|c|}{$\begin{array}{c}\text { Ensaio } 1 \\
\text { IVD } 8.00 \\
\end{array}$} & \multirow{2}{*}{$\begin{array}{c}\begin{array}{c}\text { Células de } \\
\text { levedura } / \mathrm{ml}\end{array} \\
1,30 \times 10^{9}\end{array}$} & \multirow{2}{*}{$\begin{array}{c}\begin{array}{c}\text { Viabilidade } \\
(\%)\end{array} \\
98,54\end{array}$} & \multirow{2}{*}{$\begin{array}{c}\text { Brotamento } \\
(\%)\end{array}$} \\
\hline $1^{\circ}$ & CS & & & \\
\hline & $\mathrm{CC}$ & $1,20 \times 10^{9}$ & 96,08 & 2,98 \\
\hline & CS & $1,30 \times 10^{9}$ & 98,94 & 2,32 \\
\hline & $\mathrm{CC}$ & $1,20 \times 10^{9}$ & 95,37 & 1,73 \\
\hline \multirow[t]{4}{*}{$2^{\circ}$} & $\mathrm{CS}$ & $3,0 \times 10^{9}$ & 95,28 & 1,98 \\
\hline & $\mathrm{CC}$ & $1,7 \times 10^{9}$ & 98,35 & 1,19 \\
\hline & CS & $1,3 \times 10^{9}$ & 92,82 & 0,69 \\
\hline & $\mathrm{CC}$ & $1,3 \times 10^{9}$ & 93,02 & 0,96 \\
\hline
\end{tabular}


Tabela 24 - Comportamento celular da fermentação. Ensaio 7.

\begin{tabular}{|c|c|c|c|c|}
\hline \multicolumn{2}{|c|}{$\begin{array}{c}\text { Ensaio } 1 \\
\text { IVD } 8.03 \\
\end{array}$} & \multirow{2}{*}{$\begin{array}{l}\begin{array}{c}\text { Células de } \\
\text { levedura/ml }\end{array} \\
9,30 \times 10^{8}\end{array}$} & \multirow{2}{*}{$\begin{array}{c}\begin{array}{c}\text { Viabilidade } \\
(\%)\end{array} \\
97,00\end{array}$} & \multirow{2}{*}{$\begin{array}{c}\begin{array}{c}\text { Brotamento } \\
(\%)\end{array} \\
3,54\end{array}$} \\
\hline $1^{\circ}$ & CS & & & \\
\hline & $\mathrm{CC}$ & $7,70 \times 10^{8}$ & 96,72 & 1,97 \\
\hline & CS & $9,70 \times 10^{8}$ & 91,33 & 4,34 \\
\hline & $\mathrm{CC}$ & $1,00 \times 10^{9}$ & 89,54 & 3,16 \\
\hline \multirow[t]{4}{*}{$2^{\circ}$} & CS & $1,10 \times 10^{9}$ & 90,41 & 6,98 \\
\hline & $\mathrm{CC}$ & $7,90 \times 10^{8}$ & 91,72 & 10,19 \\
\hline & $\mathrm{CS}$ & $7,60 \times 10^{8}$ & 88,41 & 9,27 \\
\hline & $\mathrm{CC}$ & $7,60 \times 10^{8}$ & 87,33 & 8,67 \\
\hline \multirow[t]{4}{*}{$3^{\circ}$} & CS & $9,10 \times 10^{8}$ & 82,00 & 16,11 \\
\hline & $\mathrm{CC}$ & $8,80 \times 10^{8}$ & 82,18 & 16,37 \\
\hline & CS & $7,80 \times 10^{8}$ & 68,31 & 10,17 \\
\hline & $\mathrm{CC}$ & $8,90 \times 10^{8}$ & 70,84 & 10,48 \\
\hline
\end{tabular}

Tabela 25 - Comportamento celular de fermentação. Ensaio 8.

\begin{tabular}{|c|c|c|c|c|}
\hline \multicolumn{2}{|c|}{$\begin{array}{c}\text { Ensaio } 1 \\
\text { IVD } 8.03 \\
\end{array}$} & $\begin{array}{c}\text { Células de } \\
\text { levedura/ml }\end{array}$ & $\begin{array}{c}\text { Viabilidade } \\
(\%) \\
\end{array}$ & $\begin{array}{c}\text { Brotamento } \\
(\%) \\
\end{array}$ \\
\hline \multirow[t]{4}{*}{$1^{\circ}$} & $\mathrm{CS}$ & $8,8 \times 10^{8}$ & 98,60 & 0,86 \\
\hline & $\mathrm{CC}$ & $8,9 \times 10^{8}$ & 96,60 & 1,70 \\
\hline & $\mathrm{CS}$ & $8,3 \times 10^{8}$ & 97,50 & 1,13 \\
\hline & $\mathrm{CC}$ & $8,3 \times 10^{8}$ & 96,80 & 1,02 \\
\hline \multirow[t]{4}{*}{$2^{\circ}$} & $\mathrm{CS}$ & $7,9 \times 10^{8}$ & 98,10 & 3,95 \\
\hline & $\mathrm{CC}$ & $7,5 \times 10^{8}$ & 97,30 & 1,23 \\
\hline & $\mathrm{CS}$ & $8,0 \times 10^{8}$ & 98,37 & 3,24 \\
\hline & $\mathrm{CC}$ & $7,9 \times 10^{8}$ & 86,56 & 2,20 \\
\hline \multirow[t]{4}{*}{$3^{\circ}$} & $\mathrm{CS}$ & $9,9 \times 10^{8}$ & 95,51 & 3,21 \\
\hline & $\mathrm{CC}$ & $1,00 \times 10^{9}$ & 95,77 & 2,81 \\
\hline & $\mathrm{CS}$ & $1,1 \times 10^{9}$ & 87,27 & 0,91 \\
\hline & $\mathrm{CC}$ & $8,1 \times 10^{8}$ & 89,44 & 1,24 \\
\hline
\end{tabular}


Tabela 26 - Comportamento celular da fermentação. Ensaio 9.

\begin{tabular}{|c|c|c|c|c|}
\hline \multicolumn{2}{|c|}{$\begin{array}{c}\text { Ensaio } 1 \\
\text { IVD } 8.10 \\
\end{array}$} & \multirow{2}{*}{$\begin{array}{c}\begin{array}{c}\text { Células de } \\
\text { levedura/ml }\end{array} \\
1,2 \times 10^{9}\end{array}$} & \multirow{2}{*}{$\begin{array}{c}\begin{array}{c}\text { Viabilidade } \\
(\%)\end{array} \\
97,40\end{array}$} & \multirow{2}{*}{$\begin{array}{c}\text { Brotamento } \\
(\%) \\
1,97\end{array}$} \\
\hline $1^{\circ}$ & CS & & & \\
\hline & $\mathrm{CC}$ & $1,3 \times 10^{9}$ & 95,97 & 1,92 \\
\hline & CS & $1,1 \times 10^{9}$ & 97,00 & 2,07 \\
\hline & $\mathrm{CC}$ & $1,2 \times 10^{9}$ & 95,60 & 1,96 \\
\hline \multirow[t]{4}{*}{$2^{\circ}$} & CS & $1,3 \times 10^{9}$ & 96,03 & 2,13 \\
\hline & $\mathrm{CC}$ & $1,3 \times 10^{9}$ & 95,87 & 2,03 \\
\hline & CS & $1,1 \times 10^{9}$ & 93,91 & 1,64 \\
\hline & $\mathrm{CC}$ & $1,1 \times 10^{9}$ & 93,11 & 0,89 \\
\hline \multirow[t]{4}{*}{$3^{\circ}$} & CS & $8,7 \times 10^{8}$ & 95,10 & 1,44 \\
\hline & $\mathrm{CC}$ & $7,6 \times 10^{8}$ & 92,00 & 0,66 \\
\hline & CS & $8,4 \times 10^{8}$ & 93,11 & 1,20 \\
\hline & $\mathrm{CC}$ & $7,5 \times 10^{8}$ & 87,92 & 0,33 \\
\hline
\end{tabular}

Tabela 27 - Comportamento celular da fermentação. Ensaio 10.

\begin{tabular}{|c|c|c|c|c|}
\hline \multicolumn{2}{|c|}{$\begin{array}{c}\text { Ensaio } 1 \\
\text { IVD } 8.19 \\
\end{array}$} & \multirow{2}{*}{$\begin{array}{l}\text { Células de } \\
\text { levedura/ml } \\
8,9 \times 10^{8}\end{array}$} & \multirow{2}{*}{$\begin{array}{c}\text { Viabilidade } \\
(\%)\end{array}$} & \multirow{2}{*}{$\begin{array}{c}\text { Brotamento } \\
(\%)\end{array}$} \\
\hline $1^{0}$ & CS & & & \\
\hline & $\mathrm{CC}$ & $8,9 \times 10^{8}$ & 98,94 & 1,37 \\
\hline & CS & $9,5 \times 10^{8}$ & 97,12 & 0,88 \\
\hline & $\mathrm{CC}$ & $8,9 \times 10^{8}$ & 98,32 & 0,71 \\
\hline \multirow[t]{4}{*}{$2^{0}$} & CS & $8,8 \times 10^{8}$ & 97,65 & 1,57 \\
\hline & $\mathrm{CC}$ & $8,7 \times 10^{8}$ & 98,10 & 1,42 \\
\hline & CS & $5,2 \times 10^{8}$ & 93,67 & 2,32 \\
\hline & $\mathrm{CC}$ & $4,9 \times 10^{8}$ & 97,31 & 1,79 \\
\hline \multirow[t]{2}{*}{$3^{\circ}$} & CS & $5,1 \times 10^{8}$ & 91,35 & 1,96 \\
\hline & $\mathrm{CC}$ & $4,9 \times 10^{8}$ & 91,04 & 1,43 \\
\hline
\end{tabular}




\section{CONCLUSÕES}

1) Os baixos Índices Volumétricos de Doença não afetam a produtividade e a eficiência da fermentação etanólica.

2) Índices Volumétricos de Doença da ordem de $8 \%$ afetam negativamente a produtividade e a eficiência da fermentação etanólica. 


\section{REFERÊNCIAS BIBLIOGRÁFICAS}

ABBOTT, E.V. \& HUGHES, C.G. Red rot. In: MARTN, J.P; ABBOTT, E.V.; HUGHES, C.G., ed. Sugarcane diseases of the word. Amsterdam, Elsevier, 1961. v. 1 , cap.12, p.262-87.

ALMEIDA, J.R. de \& SOUZA, A.F. de. A broca da cana-de-açúcar. Revista de Agricultura, Piracicaba, 11:(7/8):257-92, 1936.

AMORIM, H.V.; ZAGO, E.A.; OLIVEIRA, A.J. de. Análises para o controle da fermentação alcoólica e aparelhos de destilação. Piracicaba, ESALQ, 1979. 50p.

ARAÚJO, J.R. de; BOTELHO, P.S.M.; DEGÁSPARI, N.; ALMEIDA, L.C. de. Efeito do ataque da broca, Diatraea saccharalis em canas destinadas ao plantio. STABAçúcar, Álcool e Subprodutos, Piracicaba, 3(2):21-4, nov/dez, 1984.

BARRETO, R. Pérdidas de sacarosa em cañas de azucar dañada por el borer, Diatraea saccharalis, (Fab.) Mems. Asoc. Tec. Azuc., Cuba: 35-9, 1954.

BERGAMIN, J. A broca de cana-de açúcar. Brasil Açucareiro, Rio de Janeiro, 32(5/6):493-8, 595-612, 1948.

BEVAN, D. \& BOND, J. Microrganims in the field and mill a preliminary survey. Queensland Society Sugar Cane Techinology. Proceedings, Queensland, 38:173-243, 1971.

BOLETIM TÉCNICO COPERSUCAR,(1983) pg.79. São Paulo, mar. 1983. 60p. (Edição Especial). 
CHARPENTIER, L.J.; SANDORD, J.W. Injury and losses caused by the sugarcane borer in Lousiana. In: CONGRESS OF THE INTERNATIONAL SOCIETY OF SUGAR THECHNOLOGY, 12., Porto Rico. 1965. Proceedings. Amsterdan, Elsevier, 1965. 1383-87.

COPERSUCAR. Fermentação. I ed. Piracicaba, Centro de Tecnologia CopersucarC.T.C.- Divisão Industrial, C.T.D.I., 434p., 1987.

CRAWLEY, J.T. The losses from the sugarcane moth borer in Cuba. In: INTERNATIONAL CONFERENCE SOCIETY SUGARCANE TECHNOLOGY, 2. , Havana, 1927. Proceedings. Apud Raview of Applied Entomology. Ser. A, London, 17:466, 1929. (Resumo).

DEGÁSPARI, N.; ALMEIDA, L.C. de; MACEDO, N.; ARAÚJO, J.R. de. A queima da cana-de-açúcar, os efeitos sobre a população da broca, Diatraea saccharalis (Fabr. 1794), seus predadores e parasítos. STAB Açúcar, Álcool e Subprodutos, Piracicaba, 1 (5): 35-40, maio/jun. 1983.

DILLEWIJN, C. van. Physiology. In: . Botany of sugarcane. Walthan, Chronica Botânica, 1952. cap. 7, p.59-76.

DULCAN, C.L. \& COLMER, A.R. Coliforme associated with surgarcane plants and juice. Applied Microbiology, Washington, 12(2):173-7, 1964.

EDGERTON, C.W. Sugarcane and its diseases. Baton Rouge, Louisiana State University Press, 1959. p.69-100.

EDGERTON, C.W. \& CARVAJAL, F. Host parasite relations in red rot of sugarcane. Phytopathology, Lancaster, 34, 327-37, 1944. 
ELLIS, T.O.; ROHRIG, P.E.; ARCENEAUX, G. Stalk borer damage as affecting available sucrose in mill cane. In: CONGRESS OF THE INTERNATIONAL SOCIETY OF SUGARCANE TECHNOLOGYSTS, 10., Hawaii, 1959. Proceedings. Amsterdan, Elsevier, 1959. p. 925-38.

GALLI, F. \& CARVALHO, P.C.T. Ciclo das relações patógeno-hospedeiro. In: GALLI, F., coord. Manual de Fitopatologia. São Paulo, Agronômica Ceres, 1978. cap.9, p. 177-98.

GALLO, D. Contribuição para o conhecimento da infestação da broca da cana-de-açúcar e seu controle biológico. Piracicaba, 1953. 45p. (Doutorado - Escola Superior de Agricultura "Luiz de Queiros"/USP).

GALLO, D. Infestação de broca nas principais variedades de cana. Revista de Agricultura, Piracicaba, 25(1/2):145-55, 1954.

GALLO, D. Estudo da broca da cana-de-açúcar, Diatraea saccharalis (Fabr. 1794). Piracicaba, 1963. 68p. (Cátedra - Escola Superior de Agricultura "Luiz de Queiros"/USP).

GUAGLIUMI, P. Pragas da cana-de-açúcar; nordeste do Brasil. Rio de Janeiro, IAA, 1972. 622p. (Coleção Canavieira, 10).

INGRAM, J.W. Losses resulting from sugarcane borer injury to sugarcane in 1945. Sugar Bulletin, New Orleans, 25(2): 10, 1946.

INSTITUTO DE TECNOLOGIA DE ALIMENTOS. Determinação das perdas de sacarose na cana-de-açúcar devidas ao ataque da broca e podridão vermelha. Campinas, 1974. 121p. Projeto 44, 2/73-74. 
INTERNATIONAL comission for uniform methods of sugar analysis. In: SHNEIIDER, F. ed. Peterborough, 1979. 265p.

LANE, J.H. \& EYNON, L. Volumetric determination of reducings sugar by means of Fehling's solution, with methilene blue indicator. International Sugar Journal, West Glamorgan, 25(289): 143-9, Jan. 1923.

LOPES, J.J.C.; DEGASPARI, N.; BOTELHO, P.S.M.; LEME, J.R.A.; FERRARI, S.E.; ALMEIDA, L.C. Efeito do complexo broca/podridão na fermentação alcóolica de caldo de cana-de-açúcar. STAB. Açúcar, Álcool e Subprodutos. Piracicaba, 1(3): 40-4, jan./fev. 1983.

MAIORELLA, B.; BLANCH, H.W.; WILKE, C.R. By-Product inhibition effects on ethanolic fermentation by Saccharomyces cerevisiae. Biotechnology and Bioengineering, New York, 25: 102-21, 1983.

MATHES, R.; CHARPENTIER, L.J.; McCORMICK, W.J. Losses caused by the sugarcane borer in Louisiana. In: CONGRESS OF THE INTERNATIONAL SOCIETY OF SUGARCANE TECHNOLOGYSTS, 10., Havaii, 1959. Proceedings. Amsterdan, Elsevier, 1960. p. 919-21.

MATHES, R.; McCORMICK, W.J.; CHARPENTIER, L.J. Components of aggregate crop loss caused by sugarcane borer. In: CONGRESS OF THE INTERNATIONAL SOCIETY SUGARCANE TECNOLOGYSTS, 13., Taiwan, 1968. Proceedings. Amsterdan, Elsevier, 1969. p.1296-7.

MEADE, G.P. Analysis of the juice. In:___ Cane sugar handbook; a manual for handboog. 9.ed., New York, Wiley \& Sons. 1963. cap. 30, p.543-51. 
McKAIG JUNIOR, N. \& FORT, C.A. Chemical composition of juice from Louisiana sugarcane injured by the sugarcane borer and the red rot disease. Journal of Agricultural Research, Washington, 52(1):17-25, 1936.

NEISH, A.C. Determination of reducing sugars. In: NATIONAL RESEARCH COUNCIL OF CANADA. Analytical methods for bacterial fermentations. 2.ed. Saskatoon, 1952. p.34. (Report, 46-8-3).

NOVAS variedades Copersucar. Piracicaba, 1983. p.42-5. Edição Especial.

PRAGAS da cultura da cana-de-açúcar. In: REUNIÃO TÉCNICA AGRONÔMICA, Piracicaba, 1983. Piracicaba, Copersucar, 1983.

PRECETTI, A.A.C.M.; TERAN, F.O.; SANCHEZ, A.G. Alterações nas características tecnológicas de algumas variedades de cana-de-açúcar devidas ao dano da broca Diatraea saccharalis. Boletim Técnico COPERSUCAR. São Paulo, (40): 3-8, 1988.

RUIZ, M.A.; MARTINEZ, A.; FLORES, S. Statistical estimation of sugarcane losses due to borer attack. In: INTERNATIONAL SOCIETY OF SUGARCANE TECHNOLOGYSTS. Congress, 13., Taiwan. 1968. Proceedings. Amsterdan, Elsevier, 1969. p. 1292-5.

SANGUINO, A. Comparação de métodos de avaliação da resistência em cana-de-açúcar ao Colletotrichum falcatum. Piracicaba, 1979. 78p. (Doutorado - Escola Superior de Agricultura "Luiz de Queiros"/USP).

SCARAMUZZA, L.C. Losses to the sugar industry caused by the sugarcane borer in Cuba. International Sugar Journal, West Glamorgan, 49(578): 38-40, Feb. 1947. 
SCARAMUZZA, L.C. El control biológico y sus resultados en la lucha contra el barrenador o perforador de la cana, Diatraea saccharalis (F) en Cuba, por meio de la mosca Lixophaga diatraeae. $1^{\text {a }}$ ASSEMBLÉIA LATINO-AMERICANA DE FITOPATOLOGIA, México, p.262-92, 1951.

SILVA, G.M.A.; ROCCIA, A.O.; CAMPOS, R.B. Determinação das perdas ocasionadas pelo complexo broca-podridões na cana-de-açúcar. In: SEMINÁRIO COPERSÚCAR DA AGROINDÚSTRIA AÇUCAREIRA, 3., Águas de Lindóia, 1975. Anais. Águas de Lindóia, Copersúcar, 1975. p.241-3.

SILVA, G.M.A. \& CAMPOS, R.B. Influência do ataque do complexo broca-podridões na composição da cana-de-açúcar. In: SEMINÁRIO COPERSÚCAR DA AGROINDÚSTRIA AÇUCAREIRA, 3. Águas de Lindóia, 1975. Anais. Águas de Lindóia, Copersúcar, 1975. p. 233-40.

STEIB, R.J. \& SHILTON, S.J.P. Infection of sugar cane stalk by the red rot fungus Physalospora tucumanensis Speg. Phytopatology, Lancaster. 41: 522-28, 1951.

STOLF, R.; BOTELHO, P.S.M.; TOKESHI, H. Diminuição do índice de infestação da broca da cana-de-açúcar (Diatraea saccharalis), com o número de cortes. Álcool e Açúcar, São Paulo, 9(51): 30-7, nov./dez. 1989.

STUPIELLO, J.P. \& MORAES, R.S. de. Prejuízos causados pelo complexo brocapodridão vermelha. In: JORNADA CIENTÍFICA DA FACULDADE DE CIÊNCIAS MÉDICAS BIOLÓGICAS DE BOTUCATU, 4., Botucatu, 1974. Resumo. Botucatu, FCMBB. 1974. p.42.

TERAN, F.O. Pragas da cana-de-açúcar. In: SEMINÁRIO TÉCNICO SATAB-SUL, 9., Ribeirão Preto, 1980. Anais. Ribeirão Preto, Sociedade dos Técnicos Açucareiros do Brasil, 1980. p. 65-77. 
VALSECHI, O.; OLIVEIRA, E.R. de; BARBIN, D.; NOVAES, F.V. Estudos sobre alguns efeitos da broca Diatraea saccharalis (Fabr.) na cana-de-açúcar açucareira. Piracicaba, ESALQ/Depto de Tecnologia Rural, 1976. 140p.

VAN DINE, D.L. The sugarcane moth stalk borer. Washington, Trop. Plant. Res. Foundation, 1926. 11p. (Bulletin, 2). Apud Reviw of Applied Entomology. Ser. A, London, 14: 542, 1926. (Resumo).

VERMA, A.K.; JAISWALL, S.P.; BAJAJ, K.L.; BHETIA, I.S. A study of polyphenols in sugarcane in relation red rot disease present in the stem of sugar cane varieties. Sugar y Azucar, New York, 66(12): 11-3, dez. 1971. 